\title{
Say "No" to Discrimination, "Yes" to Accommodation: Why States Should Prohibit Discrimination of Workers Who Use Cannabis for Medical Purposes
}

\author{
Anne Marie Lofaso and Lakyn D. Cecil
}

\section{CONTENTS}

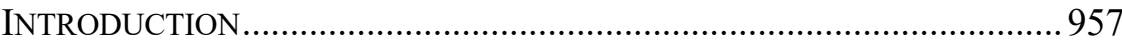

I. BACKGROUND ............................................................................. 960

A. A Very Brief History of Cannabis Regulation

in the United States

1. Early Regulation of Cannabis in the United States (1850-1937):

From Medicinal Drug Listed in the U.S. Pharmacopeia

to Restricted Drug Under Early Twentieth Century State and

Federal Law

2. The Marijuana Tax Act of 1937:

Criminalization of Marijuana Possession, Use, and Trade Under

the Guise of Taxing to Discourage Use.

3. The Controlled Substances Act of 1970:

Express Criminalization of Cannabis 969

B. Cannabis Decriminalization and Legalization:

Past, Present, and Uncertain Future 974

1. The Federalism Clash: Is Cannabis Legal or Illegal?.

\footnotetext{
* Anne Marie Lofaso is the Arthur B. Hodges Professor of Law, West Virginia University College of Law. Lakyn D. Cecil, J.D., West Virginia University College of Law, Class of 2020. The authors wish to acknowledge the enormous research support provided by the Seattle University Law Review students, especially Alejandro Monarrez (Class of 2021) and Alexandra K. Yerigan (Class of 2020), along with the patience, professionalism, and leadership provided by Klien Hilliard (Class of 2020). Much of this article was edited during the COVID-19 pandemic under stressful circumstances. The students made working under these circumstances a delightful distraction from reality. Finally, Professor Lofaso wishes to thank the Hodges Research Fund for its support of this project.
} 
2. The Importance of Recognizing Cannabis's Potent Medicinal

Purposes to Change Perceptions

II. THE ROLE OF EMPLOYMENT LAW IN PROTECTING EMPLOYEES WHO

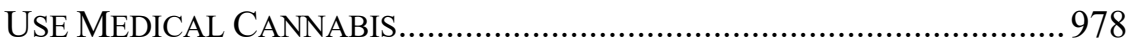

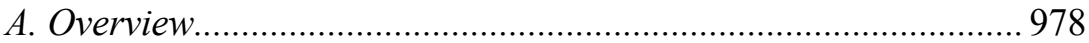

B. The Case of Colorado: Colorado Is an At-Will State with Several Exceptions That May Create a Cause of Action That Protects

Employees like Brandon Coats...................................................... 979

1. Wrongful Discharge in Violation of Public Policy .................. 979

2. Statutory Exceptions to Colorado's Employment

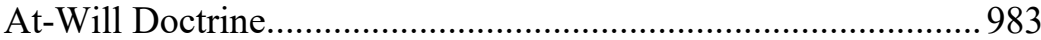

a. Lawful Activities Statute .................................................... 983

b. Disability Statutes ........................................................... 986

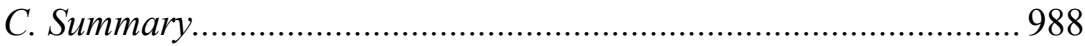

III. PROPOSED IMPLEMENTATION OF ANTI-DISCRIMINATORY LANGUAGE in Colo. Const. ARt. XVIII, SeCtion 14 AND Colo. Const. ART.

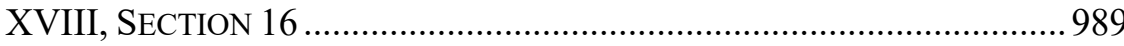

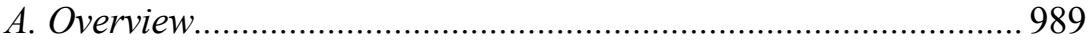

B. Survey of State Statutes .............................................................. 989

1. Nevada's Statute Regarding Medical Cannabis

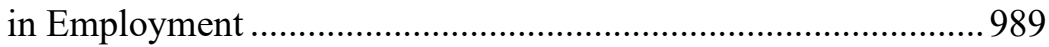

2. Oklahoma's Statute Regarding Medical Cannabis

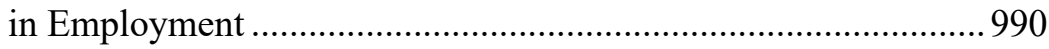

C. Proposed Language ................................................................. 991

1. Amendment to Article XVIII, Section 14 of Colorado's State

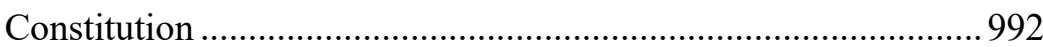

2. Amendment to Article XVIII, Section 14 of Colorado's State

Constitution

D. Reasons Why the Proposed Amendments Should Be Adopted..... 993

IV. ACCOMMODATIONS FOR EMPLOYEES LAWFUlly USING MEDICAL

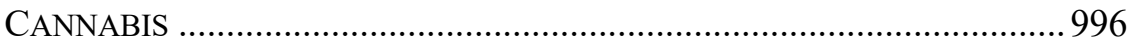

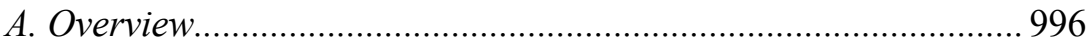

B. Exceptions Included in Proposed Amendment to Colo. Const. Art.

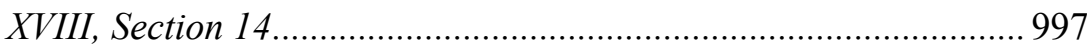

1. Why the Safety-Sensitive Position Exception is Needed......... 997 
2. Why the Employee Use of Medical Cannabis During Work

Hours Exception is Needed .........................................................998

C. Call To Colorado To Protects Its Workers ................................ 1000

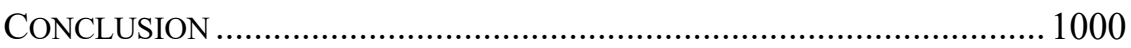

ADDENDUM................................................ 1003

\section{INTRODUCTION}

Brandon Coats was sixteen years old when, as an automobile passenger, his spinal cord was crushed in a 1996 car accident leaving over 80 percent of his body paralyzed. Now a quadriplegic confined to a wheelchair, Coats suffers severe muscle spasms and seizures. As Coats has explained, "My spinal cord is broken, so messages don't get back and forth from my brain to my body. . . . My legs still work, but they just can't get the signal. Sometimes my whole body can just seize up."1 At first, Brandon used prescription drugs to alleviate the excruciating pain that accompanies his muscle seizures. But when those drugs proved ineffective over time, Brandon's doctor's suggested that he try cannabis, ${ }^{2}$ more commonly known as medical marijuana. ${ }^{3}$

In 2000, four years after Brandon's accident, Colorado voters approved Amendment 20 to the Colorado Constitution, decriminalizing medical cannabis prescription and use in limited circumstances for approved patients with written medical consent "to address a debilitating medical condition." 4 But it would be nine years, 2009, before Brandon would register for and obtain a state-issued license to use marijuana. ${ }^{5}$

1. Daily Dose, Quadriplegic Brandon Coats Fired for Using Medical Marijuana Off Duty, MED. MARIJUANA 411 (Apr. 2, 2014), https://medicalmarijuana411.com/brandons-story/ [https://perma. cc/R26E-VA4A].

2. Id.

3. "The term medical marijuana refers to using the whole, unprocessed marijuana plant or its basic extracts to treat symptoms of illness and other conditions." NAT'L INST. OF HEALTH: NAT'L INST. on DRUg Abuse, MARIJUANA AS MEdicine 1 (2019) [hereinafter MARIJUANA AS MEdicine], https:// d14rmgtrwzf5a.cloudfront.net/sites/default/files/marijuanamedicinedrugfacts_july2019_.pdf [https:// perma.cc/2ANR-6SYP]. The term marijuana has many spellings, marihuana, in particular, being one. In this Article, we use the modern spelling of the term unless quoting directly from a primary source; in which case, we use whichever spelling is used in that source. Additionally, for purposes of this Article, we use the term cannabis to avoid the term marijuana, which has racial overtones. See RichaRd J. BONNIE \& CHARLES H. WhiteBreAD, LiNDESMith CTR., THE MARIJUANA CONVICTION: A History of MariJuAna Prohibition In the United States (1999).

4. COLO. CONST. art. XVIII, § 14.

5. Coats v. Dish Network, LLC, 2013 COA 62, \ 4, 303 P.3d 147, 149 (Colo. App. 2013), aff'd, 2015 CO 44, ๆ 5, 350 P.3d 849, 850 (Colo. 2015). 
In the meantime, Brandon obtained a job in 2007 with a satellite television company, Dish Network, as a telephone customer service representative, and worked for about two years before he began his medical cannabis treatment within the boundaries of state law. ${ }^{6}$ In 2010, Dish Network subjected Brandon to a random drug test at work on which he tested positive for tetrahydrocannabinol (THC), a component of medical cannabis. ${ }^{7}$ Brandon used cannabis within the limits of his medical license. ${ }^{8}$ He never used it at work and was never under the influence of cannabis while at work. ${ }^{9}$ Nevertheless, the following month, Dish Network fired Coats for violating the company's zero-tolerance drug policy. ${ }^{10}$ Brandon sued Dish Network under a state statute that prohibits employers from discharging an employee for "engaging in any lawful activity off the premises of the employer during nonworking hours." "1

Brandon has applied to "as many as 70 jobs" since his employment termination from Dish Network, but "[o]nce employers discover why he lost his last job, 'they kind of get a look on their face, like, I'm sorry. You're not going to get the job." 12 Finding work as a quadriplegic is not an easy task - even for someone as motivated as Brandon. ${ }^{13}$ His $\$ 750$ monthly disability benefits are not sufficient to pay his bills but he is fortunate that his mother is willing and able to help. ${ }^{14}$

Brandon's story is not unique. Just last year, the Center for Disease Control released a study finding that an "estimated $20.4 \%$ of U.S. adults

6. Id.

7. $I d$.

8. Id. (citing complaint allegations).

9. Id. at $9-7$ (citing complaint allegations).

10. Id. at 97.

11. Colo. Rev. Stat. ANN. § 24-34-402.5(1) (West 2007).

(1) It shall be a discriminatory or unfair employment practice for an employer to terminate the employment of any employee due to that employee's engaging in any lawful activity off the premises of the employer during nonworking hours unless such a restriction: (a) Relates to a bona fide occupational requirement or is reasonably and rationally related to the employment activities and responsibilities of a particular employee or a particular group of employees, rather than to all employees of the employer; or (b) Is necessary to avoid a conflict of interest with any responsibilities to the employer or the appearance of such a conflict of interest."

Id.

12. Amy Martyn, Disabled People Can Be Fired for Using Medical Marijuana, Even in Colorado, CONSUMER AFF. (Apr. 21, 2017), https://www.consumeraffairs.com/news/disabledpeople-can-be-fired-for-using-medical-marijuana-even-in-colorado-042117.html [https://perma.cc/A3PA-5H4Q].

13. Id.

14. Id. 
(50.0 million) had chronic pain and $8.0 \%$ of U.S. adults (19.6 million) had high-impact chronic pain... with higher prevalence associated with advancing age." 15

This Article addresses the question of how the law should treat medical cannabis in the employment context. Using Colorado as a primary example, we argue that states such as Colorado should amend their constitutions $^{16}$ and legislate to provide employment protections for employees who are registered medical cannabis cardholders or registered caregivers.

Part I briefly traces the legal regulation of cannabis from an unregulated medicine known as cannabis to a highly regulated illicit substance known as marijuana under the Controlled Substances Act. Our travail through this history reveals, unsurprisingly, an increasing demonization of cannabis throughout the twentieth century. That sociolegal demonization likely hindered the medical development of cannabis for at least a century. American society's negative perception of cannabis began to yield, however, as scientific evidence of cannabis's healing capacity gained popularity. Increased demand for medicinal cannabis resulted in a clash of perceptions between marijuana, the demonic influencer of immoral or criminal behavior, and cannabis, the angelic healer. It is this cognitive dissidence that helps explain the strange result of Brandon's case.

Part II surveys the role of employment law in protecting employees who use cannabis for medical purposes. We explore the public policy exception to at-will employment and various federal and state disability statutes. We conclude that judges can and should apply these measures to protect workers who may be vulnerable to discharge because of their cannabis use.

Democracies cannot and should not depend on judges to make important changes in public policies, even when those changes are to common law doctrines created by judges in the first place. Part III surveys two states' statutes - those of Nevada and Oklahoma-that protect workers who use medical cannabis from employment termination. Applying the knowledge gained from Part II, we collated what we believed to be the best language from the statutes of those two states and rewrote

\footnotetext{
15. James Dahlhamer et al., Prevalence of Chronic Pain and High-Impact Chronic Pain Among Adults-United States, 2016, 67 MORBIDITY \& MORTALITY WKLY. REP. 1001 (2018), www.cdc.gov/ $\mathrm{mmwr} / \mathrm{volumes} / 67 / \mathrm{wr} / \mathrm{mm} 6736 \mathrm{a} 2 . \mathrm{htm}$ [https://perma.cc/5KUD-ZRDL].

16. COLO. CONST. art. XVIII, $\S \S 14,16$.
} 
Colorado's constitution in a manner that would account for employees' interests and employer's legitimate concerns.

Part IV acknowledges that employers may be slow to change their medical cannabis policies. With this reality in mind, we review some best practices as to how employers can accommodate cannabis use among its workers, including appropriate exceptions to an accommodation policy that take into account employer's legitimate business interests without cutting into the essential accommodations medical cannabis users need to become or remain productive members of the U.S. workforce.

\section{BACKGROUND}

\section{A. A Very Brief History of Cannabis Regulation in the United States}

The term, marijuana, ${ }^{17}$ refers to "the dried flowers and leaves of the cannabis plant"18 that contains psychoactive compounds ${ }^{19}$ such as tetrahydrocannabinol (THC) $)^{20}$ and non-mind-altering active compounds such as cannabidiol (CBD). ${ }^{21}$ Although cannabis has a long and ancient

17. For purposes of this Article, we do not discuss the history or many important commercial uses of hemp - the part of the cannabis plant (primarily the stem) that is grown for industrial purposes such as production of rope, paper, textiles, and biofuels. See generally D. Paul Stanford, Hemp, Cannabis and Marijuana: What's the Difference?, COUNTERPunCH (Mar. 29, 2016), https://www. counterpunch.org/2016/03/29/hemp-cannabis-and-marijuana-whats-the-difference/ [https://perma.cc/ SA92-9SUD]. Hemp as a cash crop in the territorial United States dates to colonial times. See, e.g., Va. Act VIII (legislature terminated 1624) (commanding "every planter as soone as he may, provide seede of flaxe and hempe and sowe the same"). Indeed, Native Americans themselves produced hemp prior to European colonization. See, e.g., Proceedings of the Virginia Assembly 1619, reprinted in LYON GARDINER TYLER, NARRATIVES OF EARLY VIRGINIA, 1609-1625 (1946). While hemp has its own rollercoaster ride through legal history, most recently Congress passed the Agriculture Improvement Act of 2018, which amends the Controlled Substances Act of 1970 such that industrial hemp plants containing no more than 0.3 percent THC are no longer classified as a Schedule I controlled substance, thereby paving the way for legal commercial use of hemp. Agriculture Improvement Act of 2018, 7 U.S.C $\S 16390$ (2018).

18. Marijuana and Public Health, CTRS. FOR Disease Control \& PREVENTION (Mar. 7, 2018) [hereinafter CDC], https://www.cdc.gov/marijuana/faqs/what-is-marijuana.html [https://perma.cc/ZY F9-Z7Q3].

19. Psychoactive or psychotropic drugs are "substances that, when taken in or administered into one's system, affect mental processes, e.g. cognition or affect." See Psychoactive Substances, WorLD HEALTH ORG., https://www.who.int/substance_abuse/terminology/psychoactive_substances/en/ [http s://perma.cc/MD6E-NDQP].

20. MARIJUANA AS MEDICINE, supra note 3, at 3 ("THC can increase appetite and reduce nausea. THC may also decrease pain, inflammation (swelling and redness), and muscle control problems.").

21. CDC, supra note 18. 
history of use as a medicinal plant, ${ }^{22}$ it has become the most widely used illegal recreational drug in the United States, ${ }^{23}$ as evidenced by its over 1,200 nicknames. $^{24}$ The legal regulation that resulted in cannabis's transformation from medicine to instrument of evil is traced below.

1. Early Regulation of Cannabis in the United States (1850-1937):

From Medicinal Drug Listed in the U.S. Pharmacopeia to Restricted

Drug Under Early Twentieth Century State and Federal Law

First described in the United States Pharmacopeia ${ }^{25}$ (USP) in 1850, cannabis was widely utilized in the United States as an over-the-counter medicine during the nineteenth and early twentieth centuries ${ }^{26}$ Cannabis regulation commenced during President Theodore Roosevelt's administration. ${ }^{27}$ The Pure Food and Drug Act of 1906, a key piece of Roosevelt's progressive legislation, prohibited trafficking in adulterated or misbranded drugs the latter defined as follows:

22. See, e.g., ERnest L. Abel, Marihuana: The First Twelve Thousand Years 3, 200 (1980) (documenting a comprehensive history of medical cannabis tracing its early origins in China, use in India and the Middle East, and experimentation in Western medicine by the late 1880s); Theodore F. Brunner, Marijuana in Ancient Greece and Rome? The Literary Evidence, 47 BULL. HIST. MED. 344 (1973).

23. See NAT'L InSt. of HeAlth: NAT'L Inst. ON DRUg Abuse, Drug FaCtS: Nationwide TRENDS 1-2 (2015), https://d14rmgtrwzf5a.cloudfront.net/sites/default/files/drugfacts_nationtrends _6_15.pdf [https://perma.cc/UXS7-8KKK].

24. Katy Steinmetz, 420 Day: Why There Are so Many Different Names for Weed, TIME (Apr. 20, 2017), https://ime.com/4747501/420-day-weed-marijuana-pot-slang/ [https://perma.cc/G6M3$\mathrm{X} 626]$.

25. The United States Pharmacopoeia (USP) is a compendium of drug information first published in 1820 by "a group of physicians concerned about the quality and consistency of medicines." Inder Partap Singh \& Anita Szajek, What Is a Pharmacopeia?, USP (Aug. 7, 2014), https:/qualitymatters.usp.org/what-pharmacopeia [https://perma.cc/FR2E-S8QQ]. The first USP "contained formulas for the preparation of 217 drugs considered to be the "most fully established and best understood' at the time." Id.; see also F.E. Stewart, The Practice of Pharmacy as a Liberal Profession, 27 J. AM. MED. Assoc. 74, 79 (1896) (arguing for "[t]he adoption of the United States Pharmacopeia and the National Formulary as a text-book in all medical and pharmaceutic colleges . . . to elevate medical and pharmaceutic practice and cause all parties to adhere more closely to recognized standards"). In 1975, the U.S.P and National Formulary were combined in one publication to form the USP-NF, which today "contain[s] specifications (tests, procedures, and acceptance criteria) that helps ensure the strength, quality, and purity of named items." William C. Shiel Jr., Medical Definition of National Formulary, MEDICINENET (Dec. 21, 2018), https://www.medicinenet.com/script/main/art.asp?articlekey=25605 [https://perma.cc/9VJC-7SKS].

26. Mary Barna Bridgeman et al., Medicinal Cannabis: History, Pharmacology, and Implications for the Acute Care Setting, 42 PHARMACY \& THERAPEUTICS 180, 181 (2017).

27. See generally Pure Food and Drug Act of 1906, Pub. L. 59-384, 34 Stat. 768, repealed by Federal Food, Drug, and Cosmetic Act, Pub. L. No. 75-717, 52 Stat. 1040 (1938). 
Misbranding defined. That the term "misbranded," ... shall apply to all drugs, or [food product] . . the package or label of which shall bear any statement, design, or device regarding such article, or the ingredients or substances contained therein which shall be false or misleading ....

That for the purposes of this Act an article shall also be deemed to be misbranded:

In case of drugs:

First. If it be an imitation of or offered for sale under the name of another article.

Second. If . . the package fail to bear a statement on the label of the quantity or proportion of any alcohol, morphine, opium, cocaine, heroin, alpha or beta eucaine, chloroform, cannabis indica, chloral hydrate, or acetanilide, or any derivative or preparation of any such substances contained therein. ${ }^{28}$

Notice that cannabis is lumped in with "alcohol, morphine, opium, cocaine, heroin," among other drugs. ${ }^{29}$

The Pure Food and Drug Act, which took over a quarter of a century for Congress to pass, had the purpose of ensuring quality standards in the food and drug industry, so as to protect the public. ${ }^{30}$ As one contemporary commentator pointed out shortly after the law's enactment, "the principle which shall govern the department in Washington is that every article must bear a label which tells the truth, and if manufacturers put upon the market, knowingly and wilfully, substances which differ from the standards, that difference must be clearly stated ...."31 The effect of this law, that same commentator explained, was that "the United States Pharmacopceia has become of the greatest importance, inasmuch as the law requires that the standards for drugs and medicines shall be based upon that authority. The

28. Id. $\S 8$ (emphasis added).

29. Recall that, at that time, the Temperance Movement was well underway and Prohibition was a little more than a decade away. See U.S. CONST. amend. XVIII, repealed by U.S. CONST. amend. XXI. For an excellent history of the Temperance Movement and its relationship to cannabis criminalization, see Richard J. Bonnie \& Charles H. Whitebread II, The Forbidden Fruit and the Tree of Knowledge: An Inquiry into the Legal History of American Marijuana Prohibition, 56 VA. L. REV. 971, 975-90 (1970).

30. Franklin D. Jones, Historical Development of the Law of Business Competition, 36 YALE L.J. 351, 376 (1927) (explaining that "the protection of the public was the paramount consideration in the enactment of [the Food and Drug Act of 1906]").

31. See L. E. Sayre, Drug Standards with Reference to the Pure Food and Drug Law, 20 TRANSACTIONS KAN. ACAD. SCI. 48, 51 (1906). 
United States Pharmacopceia will have, therefore, far greater authority than heretofore." 32

By the time Congress had passed the Pure Food and Drug Act, or shortly thereafter, several states had restricted the production, sale, or use of cannabis for nonmedical purposes and beyond. ${ }^{33}$ For example, California closely followed the language of federal law in regulating cannabis products that were mislabeled. ${ }^{34}$ Other states restricted the sale of cannabis during this time period. For example, Indiana made it "unlawful for any person...to retail, sell, or give away any cocaine, . . . opium, morphine or heroin, cannabis indica, . . o or derivative of any of the foregoing substances, or any preparation or compound containing any of the foregoing substances" except for "a registered pharmacist, ... and they, only upon the written prescription of a duly registered physician, licensed veterinarian, or licensed dentist." 35 Maine made it "unlawful for a person to

sell, furnish, give away, or deliver opium, morphine, heroin, codeine, cannabis indica, or cannabis sativa, or any salt, compound, or preparation of said substances except upon the written prescription or order of a lawfully authorized practitioner of medicine, dentistry, or veterinary medicine, which prescription shall be dated and shall bear the name of the person giving it and the name of the person prescribed for; ... Prescriptions to be preserved for at least two years and at all times open to inspection by designated officials. ${ }^{36}$

Some states even criminalized cannabis possession. For example, Massachusetts criminalized possession except by certain pharmacists and registered healthcare officials. ${ }^{37}$ In particular, the state permitted law enforcement officials to "issue a search warrant" on "probable cause"

If a person makes complaint under oath to [law enforcement officials] authorized to issue warrants in criminal cases, that he has reason to believe that opium, morphine, heroin, codeine, cannabis indica, cannabis sativa, or any other hypnotic drug ... is kept or deposited by a person . . . in a ... vessel, or place other than by a manufacturer or jobber, wholesale druggist, registered pharmacist, registered

32. See id. at 48.

33. See infra nn.34-38.

34. Drugs to be Announced on Label, ch. 358, 1913 Cal. Stat. 767.

35. Sale and Use of Cocaine and Narcotics, ch. 118, 1913 Ind. Acts 306.

36. Id.

37. See An Act Relative to Certain Hypnotic Drugs, ch. 283, 1912 Mass. Acts 191. 
[healthcare official], employees of incorporated hospitals, or a common carrier or porter when transporting any drug mentioned .... ${ }^{38}$

Massachusetts decreed further that, upon finding any mentioned substance on the premises, the law official shall

seize and securely keep the same until final action, and to arrest the person or persons in whose possession it is found, together with all persons. Present... and to return the warrant with his doings thereon, as soon as may be, to a court or trial justice having jurisdiction in the place in which such substance is alleged to be kept or deposited. ${ }^{39}$

Between passage of the Pure Food and Drug Act in 1906 and New Deal legislation in the mid-1930s, increasingly more drugs - including alcohol-were restricted or banned altogether. ${ }^{40}$ In 1933, with the constitutional ban on alcohol repealed, ${ }^{41}$ the states and Congress were left to focus on other substances in the governments' twentieth-century war on drugs. ${ }^{42}$

\section{The Marijuana Tax Act of 1937:}

\section{Criminalization of Marijuana Possession, Use, and Trade}

Under the Guise of Taxing to Discourage Use

Between 1930 and 1937, several changes in the law and public perception, laid the groundwork for New Deal legislation regulating cannabis. First, in 1930, Harry Anslinger was appointed the first

38. Id. at $\S 1$.

39. Id.

40. See, e.g., Harrison Narcotics Tax Act of 1914, Pub. L. No. 63-223, 38 Stat 785 (banning heroin and opium use but not marijuana). The Supreme Court found the Harrison Act constitutional in United States $v$. Doremus, on grounds that the Act, which facilitated revenue collection was within "the power of Congress acting under its constitutional authority to impose excise taxes." 249 U.S. 86, 93-95 (1919).

41. U.S. CONST. amend. XXI.

42. In 1934, the National Conference of Commissioners on Uniform State Laws adopted the Uniform State Narcotic Drug Act ostensibly to create uniformity in how the states treated narcotics and to fill certain enforcement gaps in the Harrison Narcotics Tax Act. Compare Anslinger, The Reason for Uniform State Narcotic Legislation, 21 GEO. L.J. 52, 53 (1932), with Richard J. Bonnie \& Charles H. Whitebread II, The Forbidden Fruit and the Tree of Knowledge: An Inquiry Into the Legal History of American Marijuana Prohibition, 56 Va. L. Rev. 971, 1010-22 (1970). Without ceremony, the Uniform State Narcotic Drug Act added cannabis to the list of forbidden drugs. For a succinct but excellent review of the Uniform Act, see Ruth C. Stern \& J. Herbie DiFonzo, The End of the Red Queen's Race: Medical Marijuana in the New Century, 27 QuINNIPIAC L. REV. 673, 683 (2009). 
Commissioner of the Federal Bureau of Narcotics. Although initially focused on drugs such as heroin, Anslinger soon became an outspoken critic of cannabis.

In 1937, amid the New Deal era, Congress passed the Marihuana Tax Act $^{43}$ a statute that ostensibly served to nominally tax cannabis sale, in fact criminalized its use and distribution in many if not most circumstances. Section 2 of the Act, subsequently codified as Section 4751 of the Internal Revenue Code (IRC), provided for an occupational tax whereby "[i]mporters, manufacturers, and compounders of marihuana" paid a tax of "\$24 per year," producers and non-registered researchers of marijuana and healthcare officials who prescribed medical marijuana paid "\$1 per year, or fraction thereof," and non-healthcare professionals who "deal[] in, dispense[], or give[] away marihuana" paid "\$3 per year.",44 Adjusted for inflation, these taxes ranged from a high of $\$ 440.53$ to just $\$ 18.36$ - hardly amounts that would greatly affect the marijuana market. ${ }^{45}$ Section 2, subsequently codified at IRC Section 4753, further provided that at the time of paying the tax the taxpayer must "register his name or style and his place or places of business with the collector of the district in which such place or places of business are located." 46

Under Section 7 of the Marihuana Tax Act, marijuana transfers were also taxed at "\$1 per ounce" for those properly registered under Section $2 ; ;^{47}$ however, that tax rose to " $\$ 100$ per ounce" ( $\$ 1,836$ in 2020 dollars) for those who failed to register under Section $2 .{ }^{48}$ The Act also made it

unlawful for any person, whether or not required to pay a special tax and register under section 2, to transfer marihuana, except in pursuance of a written order of the person to whom such marihuana is transferred, on a form to be issued in blank for that purpose by the Secretary. ${ }^{49}$

Regulations issued under the Act required transferees of marijuana to apply for an order form with the following information: "(a) the

43. Marihuana Tax Act of 1937, Pub. L. 75-238, 50 Stat. 551

44. Id. at $\S 2$ (codified at 26 U.S.C. $\S 4751$ ). In particular, the $\$ 3$ tax was codified at 26 U.S.C. $\S 4751(5)$ and the occupational taxes were codified at 26 U.S.C. $\S \S 4751(1)-(4)$, (6).

45. See Inflation Calculator, DOLlarTimes, https://www.dollartimes.com/inflation/ [https:// perma.cc/9FG4-XVUL].

46. Marihuana Tax Act of 1937, § 2, Pub. L. 75-238, 50 Stat. 551 (codified at 26 U.S.C. § 4753).

47. Id. at $\S 7(\mathrm{a})(1)$ (codified at 26 U.S.C. $\S 4741)$.

48. Id. at $\S 7(\mathrm{a})(2)$ (codified at 26 U.S.C. $\S 4741)$.

49. Id. at $\S 6$ (codified at 26 U.S.C. $\S 4742$ ) (emphasis added). 
transferee's name, address, and, If registered, the registration number, (b) the name and address of the transferor, and (c) a description, including quantities, of the desired articles or materials to be transferred." 50 The application must be accompanied by payment of the transfer tax plus 2 cents for the order form. ${ }^{51}$ Another regulation required the transferee to submit the order form, once received, containing the same information. ${ }^{52}$ The Act further mandated that the information contained on the order form be available to law enforcement officials. ${ }^{53}$

Significantly, the Act criminalized violation of any of its provisions, including these regulations enforcing the Act's provisions. In particular, the Act provided for a fine up to $\$ 2,000$ or imprisonment of not more than five years, or both, in the court's discretion. ${ }^{54}$ The Act also made it

unlawful for ... a transferee required to pay the transfer tax imposed by [IRC] section $4741(a)$

(1) to acquire or otherwise obtain any marihuana without having paid such tax," or

(2) to transport or conceal, or in any manner facilitate the transportation or concealment of, any marihuana so acquired or obtained. ${ }^{55}$

Thus, a person who acquired marijuana and then tried to pay the tax was potentially criminally liable.

Given the harsh criminal punishments and the ease with which these regulations could be unintentionally violated, cannabis became too risky to prescribe or otherwise market. The demise of legal cannabis use for medicinal purposes came when cannabis was removed from the U.S. Pharmacopeia in 1942 "because it was believed to be a harmful and addictive drug that caused psychoses, mental deterioration, and violent behavior." 56 This action effectively removed cannabis's legitimate

50. Id.

51. 26 C.F.R. $\S 152.66$ (1969).

52. 26 C.F.R. $\S 152.69$ (1969).

53. Marihuana Tax Act of 1937, Pub. L. No. 75-238, § 11, 50 Stat. 551 (codified at 26 U.S.C. $\S 4773$ (repealed 1970)).

54. Id. at $\S 12$.

55. Id. at $\S 8$ (a) (codified at 26 U.S.C. $\$ 4744$ (a) (repealed 1970)).

56. InSt. of Med., MariJuana AND Medicine: Assessing the SCIENCE BaSE 16 (Janet E. Joy, Stanley J. Watson, Jr. \& John A. Benson, Jr. eds., 1999). 
medicinal status within the medical profession, notwithstanding its ancient history as an effective medicinal drug.

The United States government's demonization of cannabis as a narcotic associated with criminal activities was in full force by the midtwentieth century. ${ }^{57}$ During the 1950 s, Congress increased penalties for marijuana use, possession, and transport. For example, the Boggs Act of $1951^{58}$ made a first-time marijuana possession offense punishable by a minimum of two to ten years imprisonment with a fine up to $\$ 2,000$, and a third-time offense punishable up to twenty years. ${ }^{59}$ The Narcotics Control Act of 1956 (NCA) expressly made it unlawful for any unregistered person to possess or transport marijuana ${ }^{60}$ with fines for a second or subsequent offense ranging from 10 to 20 years imprisonment and fines up to $\$ 20,000 .{ }^{61}$ The NCA further amended existing law to allow officials of the Bureau of Narcotics, a division of the Treasury Department, to

make arrests without warrant for violations of any law of the United States relating ... marihuana ... where the violation is committed in the presence of the person making the arrest or where such person has reasonable grounds to believe that the person to be arrested has committed or is committing such violation. ${ }^{62}$

57. See Jacob Sullum, A Century Later, the New York Times Rejects the Anti-Marijuana Propaganda It Peddled, FORBES (Jul. 31, 2014), forbes.com/sites/jacobsullum/2014/07/31/a-centurylater-the-new-york-times-rejects-the-anti-marijuana-propaganda-it-peddled/\#3680d4a9334b [https:// perma.cc/77YU-JJWV] (the New York Times' peddling of yellow journalism at the outset of the war on cannabis picked up on a theme of marijuana-crazed Mexicans by reporting "a widow and her four children have been driven insane by eating the Marihuana plant" and that there was "no hope of saving the children's lives" (emphasis added)); see also Tom LoBianco, Report: Nixon Aide Says War On Drugs Targeted Blacks, Hippies, CNN (Mar. 24, 2016), https://www.cnn.com/2016/03/23/ politics/john-ehrlichman-richard-nixon-drug-war-blacks-hippie/index.html [https://perma.cc/68GPTMJA] (firsthand knowledge of the impetus for passing the CSA to wage a culture war on particular segments of society - albeit by declaring war on drugs instead).

58. Boggs Act of 1951, Pub. L. 82-255, 65 Stat. 767.

59. Id. (amending section 2(c) of the Narcotic Drugs Import and Export Act, as amended (21 U.S.C, § 174)).

60. Narcotic Control Act of 1956, § 101, Pub. L. 84-728, 70 Stat. 567 (amending 26 I.R.C. $\S \S$ 4744(a), (b), 4755)).

61. Id. at $\S 103$ (amending 26 I.R.C. $\S 7237)$ )

62. Id. at $\S 104$ (codified at 26 I.R.C. $\S 7606$ ). There were a few other amendments (relating to smuggling marijuana, marijuana possession on vessels, and immigration laws) that are beyond the scope of this Article. 
The ease with which this so-called tax law created criminal liability is infamously illustrated by the facts of Leary $v$. United States. ${ }^{63}$ There, Berkeley-trained, Harvard psychology professor Timothy Leary was stopped at the U.S.-Mexican border attempting to re-enter the United States when Mexico refused his entry for failing to have proper documentation. ${ }^{64}$ During the stop, customs officials noticed what appeared to be marijuana seeds on the floor of his car. ${ }^{65}$ A search of Leary's car turned up a small quantity of marijuana found primarily in "a silver snuff box [owned by Leary but found on his teenage daughter's body] containing semi-refined marihuana and three partially smoked marihuana cigarettes. ${ }^{.66}$ Leary and his teenage daughter were arrested. ${ }^{67}$ Leary was charged with (1) one count of smuggling marijuana into the United States; ${ }^{68}$ (2) one count of transportation, facilitation thereof, and concealment of marijuana after importation in violation of 21 U.S.C. $\S 176(\mathrm{a}) ;^{69}$ and (3) one count of transportation and concealment of marijuana as transferees, required to pay the transfer tax in violation of Internal Revenue Code $\S 4744(\mathrm{a})(2) .{ }^{70}$ Pending medical evaluation, ${ }^{71}$ the court sentenced Leary at the maximum level: "20 years in prison and a $\$ 20,000$ fine for violation of $\S 176 a$," and "10 years in prison and a $\$ 20,000$ fine for violation of $\S 4744(\mathrm{a})(2) . " 72$ The court ordered that the sentences run consecutively and the fines be imposed cumulatively, amounting to a total of thirty years and $\$ 40,000 .{ }^{73}$ The 2020 value of $\$ 40,000$ (1967) is $\$ 312,430.40$. Simply put, the court sentenced Leary to thirty years imprisonment and fined him the cost of a family house for

63. Leary v. United States, 395 U.S. 6 (1969).

64. Leary, 395 U.S. at 10-11.

65. Leary, 395 U.S. at 10.

66. Id.

67. Id. Leary's daughter was charged and convicted of some of the charges. The daughter, considered a minor, received a light sentence. See Leary v. United States, 383 F.2d 851, 855 (5th Cir. 1967), rev'd on other grounds, 395 U.S. 6 (1969).

68. Leary, 395 U.S. at 10. Leary was also charged with smuggling marijuana into the United States, but that count was dismissed probably because Leary purchased the substance in New York and then crossed the boundary momentarily only to be returned to the United States by Mexican officials.

69. Leary, 395 U.S. at 29-54. The Court struck down Leary's conviction on this count on due process grounds.

70. Leary, 395 U.S. at 11 (citing 26 U.S.C. § 4744(a)(2)).

71. See Leary, 383 F.2d at 854-55.

72. Leary, 395 U.S. at 11 n.5; see Leary, 383 F.2d at 854 (citing 26 U.S.C. § 7237(a), providing the statutory penalties).

73. Leary, 383 F.2d at 855 n.5. 
possessing three joints in his momentary border crossing out of Mexico because he was an unregistered person for the nominal marijuana tax. The only way this punishment makes sense is if the American imagination perceived cannabis as a powerful agent of criminal behavior and immoral conduct.

Leary successfully challenged the constitutionality of the Marihuana Tax Act on grounds that compliance with the Act violated his privilege against self-incrimination guaranteed under the Fifth Amendment. The Court explained that the Marihuana Tax Act's plain terms

compelled [Leary] to expose himself to a "real and appreciable" risk of self-incrimination ... . Sections 4741-4742 required him, in the course of obtaining an order form, to identify himself not only as a transferee of marihuana but as a transferee who had not registered and paid the occupational tax under $\S \S 4751-4753$. Section 4773 directed that this information be conveyed by the Internal Revenue Service to state and local law enforcement officials on request.

[Leary] had ample reason to fear that transmittal to such officials of the fact that he was a recent, unregistered transferee of marihuana "would surely prove a significant 'link in a chain' of evidence tending to establish his guilt" under the state marihuana laws then in effect. When [Leary] failed to comply with the Act, in late 1965, possession of any quantity of marihuana was apparently a crime in every one of the 50 States, including New York, where [Leary] claimed the transfer occurred, and Texas, where he was arrested and convicted. ${ }^{74}$

In short, the Court struck down the Act as unconstitutional because that law compelled self-incrimination. But the Court could not erase the wide-spread belief that cannabis was a powerful agent of criminal conduct.

\section{The Controlled Substances Act of 1970: Express Criminalization of Cannabis}

The 1970s and 1980s solidified the reputation of cannabis as an illicit drug associated with criminal activity. For example, one study, which compared students with free-clinic patients, claimed that " $[t]$ he use of other drugs is strongly correlated with the frequency of marijuana use in

74. Leary, 395 U.S. at 16. 
the student group, and to a lesser extent in the sample of patients." 75 Another study ostensibly showed that using hard psychedelic drugs increased with cannabis use. ${ }^{76}$ Robert DuPont, first director of the National Institute on Drug Abuse (1973-1978), coined the term "gateway drug"a drug used before using an illicit drug - to apply to alcohol and cigarettes. ${ }^{77}$ The term was soon applied to cannabis. ${ }^{78}$

One year after the Court found the Marihuana Tax Act to be unconstitutional, Congress enacted the Controlled Substances Act (CSA) to criminalize possession, use, and distribution of "marijuana." ${ }^{, 79}$ The CSA defines "the term 'marihuana' [to] mean[] all parts of the plant Cannabis sativa L., whether growing or not; the seeds thereof; the resin extracted from any part of such plant; and every compound, manufacture, salt, derivative, mixture, or preparation of such plant, its seeds or resin." ${ }^{80}$ This definition resulted in confusion because the Act appeared to regulate only one variety of cannabis, namely Cannabis sativa. There are literally hundreds of strains of cannabis ${ }^{81}$ made from domesticating two main subspecies-Cannabis sativa and Cannabis indica. ${ }^{82}$ To further

75. William McGlothlin et al., Marijuana and the Use of Other Drugs, 228 NATURE 1227, 122829 (1970); see John C. Ball, Marijuana Smoking and the Onset of Heroin Use, 7 BRIT. J. CRIMINOLOGY 408, 410-12 (Oct. 1967).

76. See Erich Goode, Multiple Drug Use Among Marijuana Smokers, 17 Soc. ProBs. 48, 6162 (1969) (a comprehensive study ostensibly showing that use of hard psychedelic drugs increased with cannabis use).

77. Denise B. Kandel, Stages and Pathways of Drug Involvement: Examining the GATEWAY HYPOTHESIS 3-5, 7 (2002).

78. Id. DuPont apparently maintains this position to this day. See Robert L. DuPont, Marijuana Has Proven to Be a Gateway Drug, N.Y. TIMES (Apr. 26, 2016), https://www.nytimes. com/roomfordebate/2016/04/26/is-marijuana-a-gateway-drug/marijuana-has-proven-to-be-a-gateway -drug [https://perma.cc/SZN9-KEQN]. But see generally LOREN L. MILLER, MARIJUANA-EFFECTS ON HUMAN BEHAVIOR 1-5, 69, 303-05 (1974) (an early compilation of scientific research pushing back on the stepping-stone or "gateway theory").

79. Comprehensive Drug Abuse Prevention and Control Act of 1970, Pub. L. 91-513, 84 Stat. 1236 (codified at 21 U.S.C. $\S \S 801-904$ ).

80. 21 U.S.C. $\S 802(16)$.

81. Nick Lindsey, How Many Different Strains of Cannabis Are There?, GREEN RUSH DAILY (Jan. 4, 2017), https://greenrushdaily.com/cannabis-strains/many-different-cannabis-strains/ [https:// perma.cc/235S-YFUA].

82. See generally The MEdicinal USES of CANNABIS AND CANNABinOIDS (Geoffrey W. Guy, Brian A. Whittle \& Philip J. Robson eds., 2004). Some scientists include a third subspecies, Cannabis ruderalis, which is sometimes classified as Cannabis sativa. The United States Department of Agriculture classifies cannabis into two primary groups: cannabis sativa and cannabis sativa indica. See Cannabis Sativa L. Ssp. Sativa Marijuana, NAT'L Res. ConSERvation SeRV., https://plants. usda.gov/core/profile?symbol=CASAS3 [https://perma.cc/F3JB-BLC5]; Cannabis Sativa L. Ssp. 
complicate matters, Cannabis sativa L. is the name normally used for hemp - a strain of Cannabis sativa that is grown specifically for its industrial uses, such as rope production.

The confusion over terminology resulted in litigation to clarify what part of the Cannabis plant the CSA regulated. In United States v. Walton, for example, the defendant argued that his conviction of one count of unlawful distribution of marijuana under the CSA was invalid because he did not distribute the particular species of cannabis named in the lawCannabis sativa $L^{83}$ The court disagreed, holding that " $\left.\mathrm{t}\right]$ he legislative history is absolutely clear that Congress meant to outlaw all plants popularly known as marijuana to the extent those plants possessed THC." ${ }^{84}$ Relying on the legislative history, the court explained that "references to the definition of marijuana in the hearings all either indicate that the witnesses believed marijuana was monotypical or that the term sativa L. encompassed all marijuana including that known as Cannabis indica." ${ }^{" 85}$ Perhaps most significantly, every appellate court that reviewed this question has drawn the same conclusion. ${ }^{86}$ Current research on the cannabis plant supports this holding insofar as researchers do not believe

Indica (Lam.) E. Small \& Cronquist Marijuana, NAT. ReS. CONSERVATION SERV., https://plants. usda.gov/core/profile?symbol=CASAI [https://perma.cc/DYD9-D7AG].

83. United States v. Walton, 514 F.2d 201, 202 (D.C. Cir. 1975).

84. Walton, 514 F.2d at 203-04.

85. Walton, 514 F.2d at 203 (citing Hearings on H.R. 6906 Before the S. Comm. on Fin., 75th Cong., 14, 23-24 (1937); Hearings on H.R. 6385 Before the H. Comm. on Ways and Means, 75th Cong., 18-42, 55, 60-61, 70-71, 76-78, 90, 122 (1937)).

86. See, e.g., United States v. Hodges, 616 Fed. App’x 961, 967 (11th Cir. 2015); United States v. Lupo, 652 F.2d 723, 728 (7th Cir. 1981); United States v. Wornock, 595 F.2d 1121, 1122 n.1 (7th Cir. 1979); United States v. Kelly, 527 F.2d 961, 964 (9th Cir. 1976); United States v. Gavic, 520 F.2d 1346, 1352 (8th Cir. 1975); United States v. Dinapoli, 519 F.2d 104, 106-07 (6th Cir. 1975); United States v. Spann, 515 F.2d 579, 582 (10th Cir. 1975); Walton, 514 F.2d at 202; United States v. Honneus, 508 F.2d 566, 574 (1st Cir. 1974); United States v. Kinsey, 505 F.2d 1354, 1354 (2d Cir. 1974); United States v. Sifuentes, 504 F.2d 845, 849 (4th Cir. 1974); United States v. Gaines, 489 F.2d 690, 691 (5th Cir. 1974); United States v. Rothberg, 480 F.2d 534, 536 (2d Cir. 1973); United States v. Moore, 446 F.2d 448, 450 (3rd Cir. 1971). But see United States v. One 1966 Chevrolet Sedan, 14 Crim. L. Rep. 2387 (S.D. Fla. 1974); United States v. Lewallen, 385 F. Supp. 1140, 1142-43 (W.D. Wis. 1974). State courts reviewing this issue also tended to broadly construe the definition of marijuana for purposes of state law. Cf. People v. Van Alstyne, 121 Cal. Rptr. 363, 373 (Cal. Ct. App. 1975); People v. Savage, 148 P.2d 654, 654 (Cal. Dist. Ct. App. 1944); Martinez v. People, 417 P.2d 485, 486 (Colo. 1966); State v. Miles, 545 P.2d 484, 486-87 (Idaho 1976), overruled on other grounds by, State v. Bottelson, 625 P.2d 1093, 1097 (Idaho 1981); State v. Luginbill, 574 P.2d 140, 144-45 (Kan. 1977); State v. Alley, 263 A.2d 66, 70 (Me. 1970); People v. Riddle, 65 Mich. App. 433, 436 (Mich. Ct. App. 1975); State v. Allison, 466 S.W.2d 712, 714 (Mo. 1971); State v. Economy, 130 P.2d 264, 269 (Nev. 1942); State v. Romero, 397 P.2d 26 (N.M. 1964); Williams v. State, 524 S.W.2d 705, 710 (Tex. Crim. App. 1975). 
there are major differences between Cannabis sativa and Cannabis indica. ${ }^{87}$

Marijuana as defined under the CSA is a Schedule I drug. Specifically, marijuana shares Schedule I(c) classification with other "hallucinogenic substances" such as 3,4-methylenedioxy amphetamine (Ecstacy), Lysergic acid diethylamide (LSD), Mescaline, and Peyote. ${ }^{88}$ That means that it is U.S. policy, as reflected in this congressional legislation, that cannabis is (A) a drug which "has a high potential for abuse," (B) a drug which "has no currently accepted medical use in treatment in the United States," and (C) that "[t]here is a lack of accepted safety for use of the drug or other substance under medical supervision." 89 Based on these congressional findings, it is "unlawful for any person knowingly or intentionally[] . . . to manufacture, distribute, or dispense, or possess with intent to manufacture, distribute, or dispense, [cannabis]." 90

The CSA thus fully criminalized cannabis, thereby reinforcing cannabis as a gateway drug related to criminal activity. ${ }^{91}$ Court

87. See Daniele Piomelli \& Ethan B. Russo, The Cannabis Sativa Versus Cannabis Indica Debate: An Interview with Ethan Russo, MD, 1 CANNABIS \& CANNABINOID RES. 44 (2016); Nicole Gleichmann, Cannabis Sativa vs. Indica: Is There a Difference?, ANALYTICAL CANNABIS (July 9, 2019), https://www.analyticalcannabis.com/articles/cannabis-sativa-vs-indica-is-there-a-difference311780 [https://perma.cc/BA9D-XQHM]. Rather, the difference between the two has more to do with perceived effects of the various strains. Indica strains are believed to have more calming effects, "physically sedating, perfect for relaxing with a movie or as a nightcap before bed." Bailey Rahn, Indica v. Sativa: What's the Difference Between the Cannabis Types?, LEAFLY (Sept. 20, 2018), https://www.leafly.com/news/cannabis-101/sativa-indica-and-hybrid-differences-between-cannabistypes [https://perma.cc/32S6-WHLX]. Sativa strains are thought to have more uplifting effects, providing "invigorating, uplifting cerebral effects that pair well with physical activity, social gatherings, and creative projects." Id. There are also hybrids that are marketed by dispensaries that have a mix of the two effects. Id. According to Ethan Russo, "[t]he way that the sativa and indica labels are utilized in commerce is nonsense .... The clinical effects of the cannabis chemovar have nothing to do with whether the plant is tall and sparse vs. short and bushy, or whether the leaflets are narrow or broad." Id. (Chemist Jeffery Raber added: "There is no factual or scientific basis to making these broad [sativa vs. indica] sweeping recommendations, and it needs to stop today. What we need to seek to understand better is which standardized cannabis composition is causing which effects, when delivered in which fashions, at which specific dosages, to which types of [consumers]."); see Marshall Morgan, Sativa vs. Indica: What's the Difference, MMJ HeAlTH (May 1, 2019), https:// mmjhealth.com/sativa-vs-indica-whats-the-difference/ [https://perma.cc/UYW6-LG38].

88. 21 U.S.C. $\S 812$ (b)(1), Schedule 1(c) (2018).

89. 21 U.S.C. $\S 812(\mathrm{~b})(1)$.

90. 21 U.S.C. $\S 841(a)-(a)(1)(2018)$.

91. However, as early as 1972, some law practitioners were advocating for the repeal of federal, state, and local laws criminalizing simple possession of cannabis for personal use because the individual and social costs substantially outweighed the benefits from prohibition. See Gerald Stern, Reforming Marijuana Laws, 58 A.B.A. J. 727, 727-30 (1972). 
jurisprudence reflects this perception. In Hutto v. Davis, the U.S. Supreme Court held that Virginia did not commit cruel and unusual punishment when a state court sentenced an individual to forty-years imprisonment and a fine of $\$ 20,000$ for possession and distribution of nine ounces of cannabis with a street value of approximately $\$ 200$ in violation of state law analogous to the CSA. ${ }^{92}$ Furthermore, several state courts of last resort have found that state legislatures do not act arbitrarily when they regulate cannabis as a dangerous drug or because cannabis is a danger to society. ${ }^{93}$

This survey, while not comprehensive, should suffice to show that cannabis - at least until recently — was perceived as a dangerous drug, the mere possession of which merited harsh criminal punishment. Reputations die hard. Accordingly, it is not surprising that many politicians and the citizens they represent remain reluctant to decriminalize cannabis. ${ }^{94}$ And

92. Hutto v. Davis, 454 U.S. 370, 370-76 (1982) (per curiam); see Rener v. Beto, 447 F.2d 20, 23 (5th Cir. 1971) (holding it was not cruel and unusual punishment for defendant to be sentenced to thirty-years in prison for possession of one marijuana cigarette); see also State v. Kelly, 678 P.2d 60, 71 (Idaho Ct. App. 1984) (finding that punishment up to "five years imprisonment and fined up to $\$ 15,000$ for growing marijuana" does not constitute cruel and unusual punishment). But see State v. Grey, 408 So.2d 1239, 1244 (La. 1982) (vacating as too harsh punishment of "eight years at hard labor and to pay a fine of $\$ 10,000$, or, in default thereof, two additional years" for possessing marijuana with the intent to distribute in violation of Louisiana law).

93. See, e.g., Dept. of Revenue of Montana v. Ranch, 511 U.S. 767, 780-82 (1994) (holding that marijuana is covered under Montana's Dangerous Drug Tax Act); In re Jones, 110 Cal. Rptr. 765, 767, 770-71(Cal. Ct. App. 1973) (The court found that "there is clear and definite evidence [from a commission report] that marijuana is a dangerous drug particularly when used by persons with preexisting borderline personalities or psychotic disorders, by young people in their formative years and perhaps by women of child-bearing potential;" and concluding that given "the dangers that can be involved in the use of marijuana, we cannot say that the penalty prescribed [five years to life sentence for the sale of marijuana] in this case though harsh and serve [sic], is out of proportion to the offense."); People v. Stark, 400 P.2d 923, 927 (Colo. 1965) ("Clearly, the use of marijuana and other drugs identified in the Colorado statute presents a danger to the public safety and welfare of the community since they are clearly related to each other and to the commission of crime."); State v. Renfro, 542 P.2d 366, 368 (Haw. 1975) (explaining that "[t]he scientific studies of marijuana are still too inconclusive to compel the conclusion that the legislature has acted arbitrarily or irrationally in treating marijuana as a substantial danger to society"); State v. Simon, 245 So.3d 1149, 1157 (La. Ct. App. 2018) (characterizing cannabis as a "controlled dangerous substance" under state law); State v. Smith, 610 P.2d 869, 875 (Wash. 1980) (en banc) (concluding that "[w]hile marijuana may not be a narcotic ... or habit forming, if the legislature reasonably has concluded that it is dangerous, it has a broad discretion in prescribing penalties for its possession").

94. For example, Attorney General Jefferson Sessions made enforcement of federal laws criminalizing cannabis a priority: "Jeff Sessions hates marijuana. Hates it, with a passion that has animated almost nothing else in his career. 'Good people don't smoke marijuana,' he has said. He even once said about the Ku Klux Klan, 'I thought those guys were okay until I learned they smoked pot.' He says that was a joke, but even so, it still says something about where he's coming from." Paul 
even if decriminalized, the political will to take the next stepaccommodating marijuana use in the workplace - seemed wholly unlikely until very recently. The following section briefly surveys the current path of cannabis decriminalization and how that path affects employment law.

\section{B. Cannabis Decriminalization and Legalization: Past, Present, and Uncertain Future}

\section{The Federalism Clash: Is Cannabis Legal or Illegal?}

The path toward cannabis legalization has taken a gradual, state-bystate approach, which has included state initiatives to decriminalize cannabis, ${ }^{95}$ provide patient access to medical cannabis, ${ }^{96}$ and legalize recreational markets. ${ }^{97}$ These developments are very recent. For example, voters in the states of Colorado and Washington passed ballot initiatives in November 2012,98 "mark[ing] the first time that any jurisdiction worldwide ha[d] legally regulated marijuana." ${ }^{\text {99 }}$ As of early 2020, 36 states

Waldman, Opinion, Why Jeff Sessions's Marijuana Crackdown Is Going to Make Legalization More Likely, WASH. POST (Jan. 5, 2018), https://www.washingtonpost.com/blogs/plum-line/wp/2018/0 1/05/why-jeff-sessions-marijuana-crackdown-is-going-to-make-legalization-more-likely/ [https://pe rma.cc/2BZC-AXX3]; see Kris Krane, The 5 Worst U.S. Senators on Marijuana Policy, ForBES (Nov. 1, 2018), https://www.forbes.com/sites/kriskrane/2018/11/01/the-5-worst-u-s-senators-on-marijuanapolicy/\#67c4e65c78fd) [https://perma.cc/QJ36-D8SG] (“'I do not have any plans to endorse the legalization of marijuana.' [Senator Majority Leader Mitch McConnell] drew a clear line between his feelings towards hemp and cannabis, stating 'It is a different plant. It has an illicit cousin which I choose not to embrace."').

95. See infra Addendum.

96. See id.

97. Eleven states and the District of Columbia have passed some legislation permitting the recreational use of cannabis. See Alaska Marijuana Legalization, Ballot Measure 2, § 1, ALASKA STAT. $\S 17.38$ (2015); The Control, Regulate and Tax Adult Use of Marijuana Act, Proposition 64, CAL. HEALTH \& SAFETY CODE $§ 11362$ (2017); Use and Regulation of Marijuana, Amendment 64, Colo. CONST. art. 18, § 16 (2018); Marijuana Possession Decriminalization Amendment Act of 2014, D.C. CODE § 20-153 (2015); Maine Citizen's Guide to the Referendum Election, Question 1, ME. STAT. tit. 28-B (2017); Ballot Initiative Question 4, MASS. GEN. LAWS ch. 94G (2016); Michigan Regulation and Taxation of Marijuana Act, MICH. COMP. LAWS § 333.27951 (2018); Initiative to Regulate and Tax Marijuana, Question 2, NeV. REV. STAT. § 453D (2016); Control, Regulation, and Taxation of Marijuana and Industrial Hemp Act, OR. Rev. StAT. § 475B; Act 86, VT. STAT. ANN. tit. 18 § 4230a (West 2018); Washington Marijuana Legalization and Regulation, Initiative 502, WASH. REV. CODE $\S 69.50$ (2012); see also Rosalie Liccardo Pacula et al., Medical Marijuana and Marijuana Legalization, 13 ANN. ReV. CliniCAL PsyChOL. 397 (2017).

98. See Use and Regulation of Marijuana, Amendment 64, CoLO. Const. art. 18, § 16 (2012); Washington Marijuana Legalization and Regulation, Initiative 502, WASH. REV. CODE $\$ 69.50$ (2012); see also Rosalie L. Pacula \& Rosanna Smart, Medical Marijuana and Marijuana Legalization, 13 ANN. Rev. CliniCAL Psychol. 397 (2017).

99. Pacula \& Smart, supra note 98. 
and Washington, D.C., have legalized cannabis use for medical purposes. ${ }^{100}$ The following map summarizes these developments:

This map shows that cannabis is still illegal in fourteen states, ${ }^{101}$ legal for medical purposes only in twenty four states, ${ }^{102}$ and legal for both

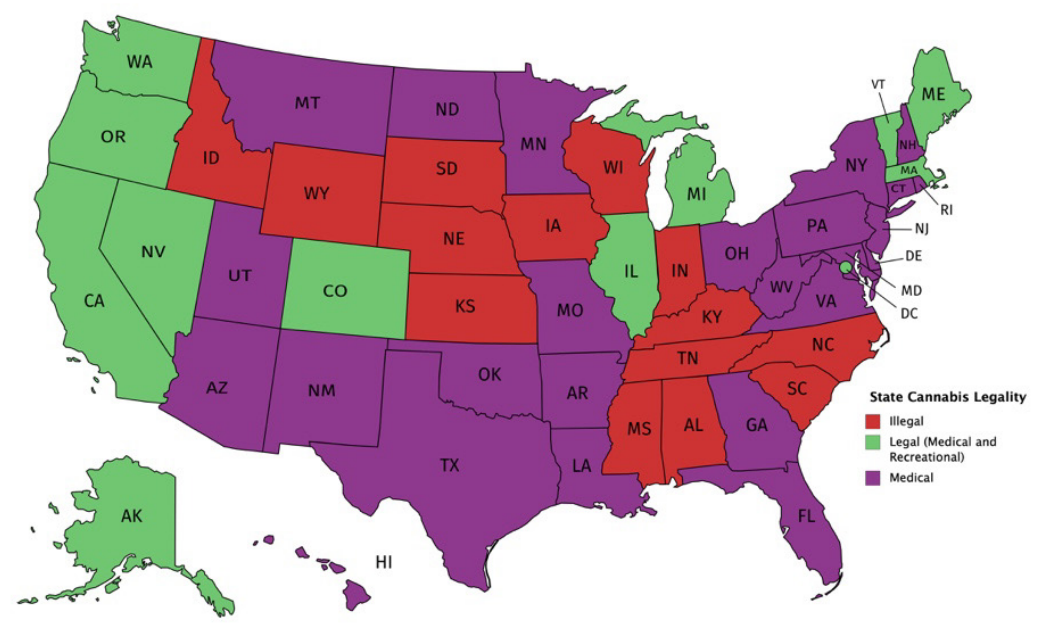

Figure 1: Legalization of Marijuana in the United States

medical and recreational purposes in eleven states and the District of Columbia. ${ }^{103}$ The driving forces behind these policy changes are threefold: "the rising state budgetary costs associated with arresting and incarcerating nonviolent drug offenders, growing scientific evidence of the therapeutic benefits of cannabinoids found in the marijuana plant, and strained state budgets that have caused legislatures to look for new source of tax revenue." 104 Accordingly, legalizing these markets would simultaneously lower the costs of incarcerating nonviolent cannabis offenders (because the conduct would no longer be unlawful) and raise

100. States with Medical Marijuana 2019, WORLD POPULATION REV., http://worldpopulation review.com/states/states-with-medical-marijuana/ [https://perma.cc/K47P-WLDA].

101. See infra Addendum.

102. Id.

103. Id.

104. See, e.g., TARa Holmes, W. VA. Ctr. On Budget \& Policy, Modernizing West VIRGINIA'S MARIJUANA LAWS-POTENTIAL BENEFITS OF DECRIMINALIZATION, MEDICAL MARIJUANA AND LEGALiZATION (2016); Pacula \& Smart, supra note 98. 
state revenue at a time when state coffers are deplete. ${ }^{105}$ It would also have the added benefit of unlocking and developing cannabis's ancient medicinal uses.

But while states have commenced a steady flow of legislation decriminalizing cannabis and, in some cases, legalizing it for medical or recreational purposes, the federal government has continued to regulate cannabis as a dangerous Schedule I drug under the CSA. On one side of this debate are the thirty-five states that have legalized the medical use of cannabis, each having created a specific set of rules for regulating cannabis. ${ }^{106}$ These rules "are customized to each state's unique policies, interests, financial resources, and fiscal plans for excess tax revenue."107 On the other side is the federal government. And while some Presidential administrations have only loosely enforced laws criminalizing marijuana use and possession, the Department of Justice under President Donald Trump has taken a strict enforcement approach to these federal crimes. ${ }^{108}$ Not surprisingly, this "lack of uniformity between the federal and state law results in consumer confusion and inconsistent compliance with the current laws governing marijuana use and distribution within the United States." 109

105. See, e.g., Jonathan P. Caulkins et. al., High Tax States: Options for Gleaning Revenue from Legal Cannabis, 91 OR. L. REV. 1041 (2013) (discussing excise taxes and explaining how legalization could produce other government revenues including, licensing fees, drug tourism, generate sale tax revenue from purchasing equipment and necessary supplies); David G. Evans, The Economic Impacts of Marijuana Legalization, 7 J. GLOBAL DRUG POL'Y \& PRAC. 1 (2013); Michael Vitiello, Legalizing Marijuana: California's Pot of Gold?, 2009 WIS. L. REV. 1349, 1380 (2009) (discussing the economic benefits of reduced prison population); see also Jody Murphy, Opinion, Legalize and Tax Marijuana, and Then Fund Health Care with That Revenue, Charleston GazeTte-Mail (Jan. 3, 2020), https://www.wvgazettemail.com/opinion/op_ed_commentaries/jody-murphy-legalize-and-tax-mari juana-and-then-fund-health/article_e4b3b9f1-0e-28-5a9e-a353-fb82262a416f.html [https://perma.cc/ N7MN-F9NU].

106. Silvia Irimescu, Note, Legalizing Marijuana: State and Federal Issues: Marijuana Legalization: How Government Stagnation Hinders Legal Evolution and Harms a Nation, 50 GoNZ. L. REV. 241, 242 (2015). This note is a few years old and therefore cites to fewer states than have currently legalized cannabis for medical use. See infra Addendum for up-to-date statistics.

107. Id.

108. See Sam Kamin, Opinion, The Trump Administration's Nonsensical Stance on Marijuana, WASH. POST (Feb. 27, 2017), https://www.washingtonpost.com/opinions/the-trump-administrationsnonsensical-stance-on-marijuana/2017/02/27/b5aab714-fd07-11e6-8f41-ea6ed597e4ca_story.html) [https://perma.cc/Z8LC-LM25]; Charlie Savage \& Jack Healy, Trump Administration Takes Step that Could Threaten Marijuana Legalization Movement, N.Y. TIMES (Jan. 4, 2018), https://www. nytimes.com/2018/01/04/us/politics/marijuana-legalization-justice-department-prosecutions.html) [https://perma.cc/KEJ5-DNBE].

109. Irimescu, supra note 106, at 242. 
2. The Importance of Recognizing Cannabis's Potent Medicinal Purposes to Change Perceptions

While cannabis cultivation could help diversify the economies of many cash-strapped states and cannabis decriminalization would remove many financial and other burdens from our criminal justice system, it is dubious that this industry could gather widespread public support if cannabis did not have significant medical efficacy. This is especially true in light of its reputation as a gateway drug. For these reasons, one of the most significant steps in the history of cannabis legalization relates to legislation allowing cannabis for medicinal purposes.

Medical cannabis ${ }^{110}$ refers to the use of an unprocessed cannabis plant to treat medical conditions and to provide pain relief ${ }^{11}$ in both terminal and nonterminal patients. ${ }^{12}$ Those who support the use of cannabis for medical purposes, such as Brandon Coats's physicians, support the claim that its use is justified to prevent unnecessary suffering from "chronic and unbearable pain that persists until death." 113 Physicians have typically prescribed medical cannabis to patients when more conventional treatments have been ineffective. ${ }^{114}$ That seventy-two percent of U.S. states now recognize the importance of the medicinal use of cannabis "illustrates the rising public support for the use of medical marijuana." 115

Scientific studies have repeatedly supported using cannabis for medical purposes to treat sundry medical conditions, especially those that cause chronic, excruciating, or intractable pain. ${ }^{116}$ With these and other studies in mind, several states have taken legislative steps ${ }^{117}$ toward decriminalizing cultivating, transferring, and ingesting marijuana for

110. Scientific study of the chemicals in marijuana, called cannabinoids, has led to two FDAapproved medications that contain cannabinoid chemicals in pill form. See MARIJUANA AS MEDICINE, supra note 3.

111. Id.

112. See Kathleen T. McCarthy, Conversations About Medical Marijuana Between Physicians and Their Patients, 25 J. LEGAL MED. 333, 334 (2004).

113. See id. Cannabis is more often prescribed for cancer patients. Id.

114. See Lester Grinspoon \& James B. BaKalar, Marihuana: The Forbidden Medicine (1997); McCarthy, supra note 112, at 334.

115. See supra Figure 1, at p. 976; infra Addendum. See generally Elizabeth Rodd, Note, Light, Smoke, and Fire: How State Law Can Provide Medical Marijuana Users Protection from Workplace Discrimination, 55 B.C. L. REV. 1759, 1794 (2014).

116. See generally McCarthy, supra note 112.

117. For a review of those state statutes, see infra Addendum. 
medicinal purposes. ${ }^{118}$ For example, in 1996, "California became the first state to permit legal access to and use of botanical cannabis for medicinal purposes under physician supervision with the enactment of the Compassionate Use Act."119

As discussed above, thirty-six states and Washington, D.C. now permit the use of medical cannabis. ${ }^{120}$ Accordingly, federal prohibitions on cultivating, selling, and using cannabis ${ }^{121}$ are inconsistent with historical uses of cannabis for medicinal purposes. ${ }^{122}$ This inconsistency, in turn, creates problems for workers, like Brandon, who rely on medical cannabis.

\section{THE ROLE OF EMPLOYMENT LAW IN PROTECTING EMPLOYEES WHO USE MEDICAL CANNABIS}

\section{A. Overview}

To understand how this historical survey of cannabis regulation in the United States pertains to Brandon's case, it is necessary to understand another legal framework - the law of wrongful discharge. By way of background, nearly every state in the United States uses the employment at-will doctrine as a default rule. ${ }^{123}$ This means that either an employer or an employee may terminate the employment relationship for any reason-

118. States with medical marijuana laws generally have some form of patient registry, which may provide some protection against arrest for possession up to a certain amount of marijuana for personal medical use. State Medical MariJuana Laws, NAT'L Conf. ON State LegisLatures (2019), http://www.ncsl.org/research/health/state-medical-marijuana-laws.aspx [https://perma.cc/QV 6A-UYDP].

119. Mary Barna Bridgeman \& Daniel T. Abazia, Medicinal Cannabis: History, Pharmacology, and Implications for the Acute Care Setting, 42 PHARMACY \& THERAPEUTICS 180, 181 (2017) (citing CAL. Health \& SAFETY CODE $\S 11362.5$ (West 1996)).

120. See supra Figure 1, at p. 976; infra Addendum.

121. See 21 U.S.C. $\S 841$ (2018).

122. See McCarthy, supra note 112 , at 334-36.

123. Montana is the only state to have rejected the presumption of at-will employment and instead has created a cause of action for wrongful discharge grounded in lack of good-cause employment termination. See MonT. CODE ANN. § 39-2-904 (2020); Blehm v. St. John's Lutheran Hosp., 2010 MT 258, ๆ 18, 246 P.3d 1024, 1027 (Mont. 2010) (applying Montana statute). Puerto Rico and the Virgin Islands also require just cause for employment termination. See P.R. LAwS ANN. tit. 29, § 185a-m (2009); V.I. CODE ANN. tit. 24, §§ 76-79 (2019). 
good or bad-or for no reason at all. ${ }^{124}$ This is a common law rule. ${ }^{125}$ Accordingly, judges in most states have developed exceptions to this rule, which allow for wrongful discharge claims. State legislatures and Congress can also enact state and federal statutory exceptions to support wrongful discharge claims.

\section{B. The Case of Colorado: \\ Colorado Is an At-Will State with Several Exceptions That May Create a Cause of Action That Protects Employees like Brandon Coats}

Under Colorado state law, "an employee hired for an indefinite period of time is presumed to be an 'at will' employee whose position can be terminated without cause or notice and whose termination does not give rise to a cause of action." ${ }^{26}$ As with most states, there are exceptions to this default rule. As discussed below, Colorado has both common law and statutory exceptions. Moreover, federal law can create a cause of action that supersedes the at-will presumption. ${ }^{127}$

\section{Wrongful Discharge in Violation of Public Policy}

The Colorado Supreme Court has recognized a public policy exception to the employment at-will presumption. ${ }^{128}$ This narrow exception provides an employee with a cognizable claim for wrongful termination "if the discharge of the employee contravenes a clear mandate of public policy." ${ }^{29}$ An employee may state a claim for wrongful discharge in violation of public policy by alleging the following: (1) the individual was employed by the employer; (2) the employer discharged the employee; and (3) the discharge was "in retaliation for exercising a

124. See, e.g., Payne v. Western \& Atl. R.R., 81 Tenn. 507, 518-19 (Tenn. 1884) (observing that "[i]f the service is terminable at the option of either party, it is plain no action would lie even to the employe[e]; for either party may terminate the service, for any cause, good or bad, or without cause, and the other cannot complain in law"), overruled on other grounds by Hutton v. Walter, 179 S.W. 134 (Tenn. 1915).

125. See generally Clyde W. Summers, Employment at Will in the United States: The Divine Right of Employers, 3 U. PA. J. LAB. \& EMP. L. 65 (2000).

126. Healion v. Great-West Life Assurance Co., 830 F. Supp. 1372, 1375 (D. Colo. 1993). The Colorado Supreme Court recently rearticulated this statement of state law. See Lucht's Concrete Pumping, Inc. v. Horner, 255 P.3d 1058, 1061 (Colo. 2011) (en banc) (stating that "an employer may terminate an at-will employee at any time without incurring any legal liability").

127. For example, it is not a defense to a race discrimination claim that the employee was atwill. See 42 U.S.C. $\S 2000 \mathrm{e}-2$ (2018).

128. Martin Marietta Corp. v. Lorenz, 823 P.2d 100, 104-05 (Colo. 1992) (en banc).

129. Id. at 107 (internal quotations and citations omitted). 
job-related right or performing a specific statutory duty" or "would undermine a clearly expressed public policy." 130 The public policy itself should be a "widely accepted,"131 "clearly mandated,"132 and "substantial"" 133 matter that affects society at large "rather than a purely personal or proprietary interest of the [employee] or employer." 134 Accordingly, the "public policy must concern behavior that truly impacts the public in order to justify interference into an employer's business decisions." 135 Sources of a public policy exception, under Colorado law, are not limited to the state constitution or its statutes but can include regulations and professional codes of conduct. ${ }^{136}$

Could Brandon have successfully sued Dish Network for wrongful discharge sounding in public policy? To simplify the analysis, let's assume that Brandon, like most workers, was an at-will employee of his employer and that his employer, Dish Network, discharged him for using cannabis. To determine whether Brandon has a viable cause of action for wrongful discharge, we must determine whether his discharge was "in retaliation for exercising a job-related right or performing a specific statutory duty, or ... would undermine a clearly expressed public policy." 137 Using medical cannabis is not normally a "job-related right." Nor does it constitute performance of a "specific statutory duty." Accordingly, we must determine whether using medical cannabis in these circumstances "would undermine a clearly expressed public policy"138 that is a "widely accepted,"139 "clearly mandated,"140 and "substantial... matter that

130. Galvan v. First Vehicle Servs., Inc., No. 19-cv-02143-PAB-KMT, 2020 WL 1166857, at *3 (D. Colo. Mar. 11, 2020) (citing Kearl v. Portage Env't, Inc., 205 P.3d 496, 499 (Colo. App. 2008)). 131. Crawford Rehab. Servs., Inc. v. Weissman, 938 P.2d 540, 552 (Colo. 1997) (en banc).

132. Rocky Mountain Hosp. \& Med. Serv. v. Mariani, 916 P.2d 519, 525 (Colo. 1996) (en banc) (explaining that "public policy must be clearly mandated such that the acceptable behavior is concrete and discernible as opposed to a broad hortatory statement of policy that gives little direction as to the bounds of proper behavior").

133. Crawford, 938 P.2d at 552.

134. Id.

135. Rocky Mountain, 916 P.2d at 525; accord Crawford, 938 P.2d at 552; Kearl v. Portage Env't, Inc., 205 P.3d 496, 499 (Colo. App. 2008); Galvan, 2020 WL 1166857, at *3.

136. See, e.g., Rocky Mountain, 916 P.2d at 524-25 (discussing the split in jurisdictions over the sources of public policy and expressly holding that codes of professional conduct may constitute one such source).

137. Galvan, 2020 WL 1166857, at *3 (citing Kearl, 205 P.3d at 499).

138. Id.

139. Crawford, 938 P.2d at 552.

140. Rocky Mountain, 916 P.2d at 525. 
affects society at large rather than [Brandon's] purely
personal ... interest ....,141

Brandon's case comes down to whether he can find a public policy. Colorado's constitution is likely a dead-end source for that inquiry. Although Colorado's constitution grants its residents the freedom to use cannabis under Amendment XVIII, Section 16(1)(a), ${ }^{142}$ it expressly does not extend protection of that constitutional freedom to employees under Amendment XVIII, Section 16(6)(a). ${ }^{143}$ It is worth deconstructing just what these two constitutional provisions mean. Section 16(1)(a) declares that Colorado has the following three interests for constitutionally promising not to interfere with its residents' cannabis use: (1) "efficient use of law enforcement resources;" (2) "enhancing revenue for public purposes;" and (3) "individual freedom." "144 But Section 16(6)(a) explains that the freedom to use cannabis is not a freedom from employer regulation of employee cannabis use: "Nothing in this section is intended to require an employer to permit or accommodate the use, consumption, possession, transfer, display, transportation, sale or growing of marijuana in the workplace or to affect the ability of employers to have policies restricting the use of marijuana by employees." Simply put, Section 16(6)(a) anticipates that the Colorado constitution could be a public-policy source for cannabis use among workers and therefore grants employers a constitutional right to regulate cannabis use among workers notwithstanding those workers' freedom to use cannabis.

The inquiry does not end here, however; Brandon can also search for a statutory source of public policy. His best bet would likely be Colorado's medical cannabis laws coupled with that state's most recent law regulating medical cannabis, which went into effect on January $1,2020 .{ }^{145}$ Under that law, Colorado currently offers medical cannabis registry identification $\operatorname{cards}^{146}$ to patients with "a disabling medical condition." 147 The statute

141. Crawford, 938 P.2d at 552.

142. COLO. CONST. art. XVIII, § 16(1)(a).

143. Id. § 16(6)(a).

144. Id. $\S 16(1)(\mathrm{a})$.

145. See generally COLO. ReV. STAT. § 25-1.5-106 (2019).

146. The Colorado statute defines registry identification card to be "the nontransferable confidential registry identification card issued by the state health agency to patients and primary caregivers pursuant to..." the medical marijuana program established under the Colorado Constitution, Colo. Const. art. XVIII, § 14. COLO. ReV. STAT. § 25-1.5-106(2)(e) (2019).

147. See id. § 25-1.5-106(2)(a.7) (2019). 
also grants to patients, who use medical cannabis consistent with state law, an affirmative defense to certain state criminal laws:

[A] patient with a disabling medical condition ... charged with a violation of the state's criminal laws related to the patient's medical use of marijuana will be deemed to have established an affirmative defense to such allegation where:

(I) The patient was previously diagnosed by a physician as having a disabling medical condition;

(II) The patient was advised by his or her physician, in the context of a bona fide physician-patient relationship, that the patient might benefit from the medical use of marijuana in connection with a disabling medical condition; and

(III) The patient... [was] in possession of amounts of marijuana only as permitted under this section. ${ }^{148}$

The public policy behind this statute - to augment medical cannabis access to needy patients - is clearly stated in Section 1, which reads that the State "declares that it is necessary to implement rules to ensure that patients suffering from legitimate debilitating medical conditions are able to safely gain access to medical marijuana . ..."149 The statute authorizes access to the extent consistent with state constitutional, statutory and regulatory law. ${ }^{150}$

The question for the Brandons of Colorado is whether this section creates a clearly mandated, widely accepted, and substantial matter that affects society at large - a matter that has sufficient impact on the public to justify interference into an employer's business decisions - rather than a purely personal interest. ${ }^{151}$ In most cases, the answer to that question will come down to a balancing of interests - whether the employee's medical needs outweigh the employer's business interests because the legislative policy behind legalizing medical cannabis meets the public policy test. First, the policy is clearly mandated. It is expressly stated in Section 1 of the statute. Second, Colorado's long-standing support of medical cannabis use coupled with its permissible use of even recreational cannabis suggests that the policy is widely accepted. Third, courts are likely to find the matter

148. Id. § 25-1.5-106(2.5a) (2019)

149. Id. § 25-1.5-106(1) (2019).

150. See id.

151. See supra nn.130-136 and accompanying text. 
to be substantial to the extent that employees couch those interests in the human right language of wellness and health management - a message that is likely to be heard loud-and-clear in a post-COVID-19-pandemic world. To be sure, employers will argue that medical cannabis is a purely personal matter because it affects individual employees. But that contention misses Colorado's policy point about augmenting medical cannabis access to patients who suffer from debilitating medical conditions. ${ }^{152}$ This is a right that "inures to the benefit of the public at large[,]" not just to Brandon. ${ }^{153}$ The question for courts, then, is whether the employer's concerns in any particular case outweigh this policy. The answer to that question will depend on the type of job and the concerns that employers raise. Perhaps employers' safety concerns about flight instructors outweigh the public policy no matter how substantial it is. But it is hard to imagine how employers' concerns about telephone customer service representatives can outweigh such a substantial interest-unless courts are unpersuaded that the policy is a public policy.

\section{Statutory Exceptions to Colorado's Employment At-Will Doctrine}

A second course of action for the Brandons of Colorado is to use either a state or federal employment statute, which expressly creates an atwill exception. The two most likely candidates are Colorado's Lawful Activities Statute ${ }^{154}$ and the Americans with Disabilities Act (ADA), ${ }^{155}$ together with its analogous state civil rights law. ${ }^{156}$

\section{a. Lawful Activities Statute}

Brandon himself utilized the Lawful Activities Statute, which makes it unlawful "for an employer to terminate the employment of any employee due to that employee's engaging in any lawful activity off the premises of the employer during nonworking hours." ${ }^{157}$ In fact, this statute seems tailor-made for Brandon's situation because Dish Network discharged Brandon for using medical cannabis - a lawful activity under Colorado law_during nonworking hours.

152. Colo. ReV. StAT. § 25-1.5-106(1) (2019).

153. See Foley v. Interactive Data Corp., 765 P.2d 373, 379 (Cal. 1988).

154. See COLO. REV. STAT. § 24-34-402.5 (2019).

155. The Americans with Disabilities Act (ADA) is the dominant source of disability rights in the United States. See Americans with Disabilities Act of 1990, 42 U.S.C. § 12101 (2009).

156. See, e.g., COLO. REV. STAT. § 24-34-402 (2019).

157. Id. § 24-34-402.5 (2019). 
The Colorado Supreme Court rejected Brandon's argument under the Lawful Activities Statute. The court held that Brandon's use of cannabis for medical purposes under a Colorado license was not a "lawful activity" under the Colorado statute because medical cannabis use is unlawful under federal law, ${ }^{158}$ namely, the Controlled Substances Act. ${ }^{159}$ The court provided the following analysis. First, it reviewed "the commonly accepted and understood meaning" of the term "lawful" and concluded that the term means " "that which is "permitted by law' or, conversely, 'that which is not contrary to, or forbidden by law." "160 Next, it reviewed the question whether medical cannabis use "that is licensed by the State of Colorado but prohibited under federal law is 'lawful' for purposes of [the Lawful Activities Statute]."161 Brandon argued that it was, and Dish argued that it was not. The court agreed with Dish, explaining:

Nothing in the language of the statute limits the term "lawful" to state law. Instead, the term is used in its general, unrestricted sense, indicating that a "lawful" activity is that which complies with applicable "law," including state and federal law. We therefore decline Coats's invitation to engraft a state law limitation onto the statutory language. ${ }^{162}$

Several other state courts have reached results in disagreement with the Colorado Supreme Court. ${ }^{163}$ For example, in Callaghan v. Darlington Fabrics Corporation, the Rhode Island Superior Court ${ }^{164}$ held that the CSA did not supersede the state's medical cannabis law. ${ }^{165}$ In that case, Christine Callaghan alleged that Darlington Fabrics refused to hire her for

158. Coats v. Dish Network, L.L.C., 2015 CO 44, $₫$ 11, 20, 350 P.3d 849, 851, 853 (Colo. 2015).

159. 21 U.S.C. $\$ 841$ (2018); see supra nn.79-80 and accompanying text.

160. See Coats, 2015 CO at 17 (quoting Coats v. Dish Network, L.L.C., 2013 COA 62, $\uparrow 13$, 303 P.3d 147, 150 (Colo. App. 2013)).

161. See id. ๆ 18 (citing Colo. Rev. Stat. § 24-34-402.5 (2019)).

162. See id.

163. See generally Zachary D. Bombatch, Cases Addressing Employee Protections Under Marijuana Laws Remain Inconsistent, NAT'L L. REV. (Oct. 31, 2018), https://www.natlawrevi ew.com/article/cases-addressing-employee-protections-under-marijuana-laws-remain-inconsistent [https://perma.cc/Y3WX-V8V8].

164. The Superior Court of Rhode Island is the court with "original jurisdiction in all felony proceedings, in civil cases where the amount in controversy exceeds $\$ 10,000$, and in equity matters" and with "concurrent jurisdiction with the District Court in civil matters in which the amount in controversy is between $\$ 5,000$ and $\$ 10,000$." See Superior Court: A Message From Presiding Justice Alice B. Gibney, R.I. JUDICIARY, https://www.courts.ri.gov/Courts/SuperiorCourt/Pages/default.aspx [https://perma.cc/NR6C-8LVA].

165. Callaghan v. Darlington Fabrics Corp., No. PC-2014-5680, 2017 WL 2321181 (R.I. Super. Ct. May 23, 2017). 
an internship because she held a medical marijuana card in violation of both the Hawkins-Slater Act ${ }^{166}$ or the Rhode Island Civil Rights Act (RICRA). ${ }^{167}$ The court explained that "the CSA is concerned with stopping the illegal trafficking and use of controlled substances. To read the CSA as preempting either the Hawkins-Slater Act or RICRA would imply that anyone who employs someone that violates federal law is thereby frustrating the purpose of that law."168

In Smith v. Jensen Fabricating Engineering, Inc., a Connecticut state trial court adopted Rhode Island's view. ${ }^{169}$ There, the employer refused to hire employee Smith when the employer learned that Smith was using cannabis to treat the symptoms associated with Post-Traumatic Stress Disorder (PTSD), consistent with Connecticut's Palliative Use of Marijuana Act (PUMA). ${ }^{170}$ The court concluded that the CSA did not preempt PUMA, relying on language in the CSA itself, which expressly does not preempt state law "unless there is a positive conflict between that provision of this subchapter and that State law so that the two cannot consistently stand together." ${ }^{\prime 11}$ The court explained:

In and of itself, [PUMA] does not authorize the use of marijuana. [PUMA] simply says that an employer may not fire or refuse to hire an employee solely because that individual uses marijuana in compliance with PUMA's requirements and in a manner that has no effect on that employee's workplace performance or the employer's ability to obtain business. The CSA says nothing about these issues. ${ }^{172}$

Similarly, in Chance v. Heinz Kraft Foods Company, in the context of a wrongful termination and employment discrimination case where the employee, a medical cannabis user, tested positive for cannabis, the Delaware Superior Court held that the CSA did not preempt the antidiscrimination provision of the Delaware Medical Marijuana Act

166. "No . . . employer ... may refuse to ... employ, ... or otherwise penalize, a person solely for his or her status as a cardholder." R.I. GEN. LAWS $\S$ 21-28.6-1 to 28.6-12 (2019) (commonly known as the "The Edward O. Hawkins and Thomas C. Slater Medical Marijuana Act").

167. Rhode Island Civil Rights Act (RICRA), R.I. GEN. LAWs $\S \S 42-112-1$ to 112-2 (1990).

168. Callaghan, 2017 WL 2321181, at*14.

169. Smith v. Jensen Fabricating Eng'r, Inc., No. HHDCV186086419, 2019 WL 1569048, at *4 (Conn. Super. Ct. Mar. 4, 2019).

170. Id. at *1 (citing CONN. GeN. STAT. § 21a-408a-v).

171. Id. at *3 (citing 21 U.S.C. $\S 903$ (2018)).

172. Id. (citing CONN. GEN. STAT. § 21a-408p(b)(3)). 
(DMMA). ${ }^{173}$ In that case, the court observed that "the DMMA explicitly prohibits employers from disciplining employees who use marijuana for medical reasons, and who fail drug tests because of it." ${ }^{\prime 17}$ The court further noted that at least eight other states-Arizona, Connecticut, Illinois, Maine, Nevada, New York, Minnesota, and Rhode Island-have similar statutory provisions. ${ }^{175}$

\section{b. Disability Statutes}

The other option for the Brandons of Colorado is to allege a cause of action based on the ADA or the Colorado civil rights statutory equivalent. Both the $\mathrm{ADA}^{176}$ and the Colorado civil rights statute ${ }^{177}$ prohibit employers from taking an adverse employment action against an employee because of that employee's disability. To make out a case for employment discrimination under the ADA, Brandon must show that, "at the time he was fired, (1) he was a disabled person as defined by the ADA; (2) he was qualified, with or without reasonable accommodation, to perform the essential functions of his job; and (3) he was fired because of his disability." 178

Brandon could readily show that he is a disabled person under the ADA, which defines the "term 'disability' [to] mean[], with respect to an individual ... a physical or mental impairment that substantially limits one or more major life activities of such individual." 179 To satisfy this

173. Chance v. Kraft Heinz Foods Co., No. K18C-01-056 NEP, 2018 WL 6655670, at*3 (Del. Super. Ct. Dec. 17, 2018).

174. Id. at*3, n.18 (citing Del. CoDE ANN. tit. 16, § 4905A(a)(3) (2011)). 2017)).

175. Id. (citing Noffsinger v. SSC Niantic Operating Co., 273 F. Supp. 3d 326, 331 (D. Conn.

176. See generally 42 U.S.C. $\S 12101$ (2018). The ADA prohibits employers from "discriminat[ing] against a qualified individual on the basis of disability in regard to job application procedures, the hiring, advancement, or discharge of employees, employee compensation, job training, and other terms, conditions, and privileges of employment." 42 U.S.C. $§ 12112$ (2018).

177. The Colorado civil rights statute makes it an "unfair employment practice... [f]or an employer to refuse to hire, to discharge, to promote or demote, to harass during the course of employment, or to discriminate in matters of compensation, terms, conditions, or privileges of employment against any person otherwise qualified because of disability." COLO. REV. STAT. § 2434-402 (2019).

178. Carter v. Pathfinder Energy Servs., Inc., 662 F.3d 1134, 1142 (10th Cir. 2011).

179. 42 U.S.C. $\S 12102(1)(A)$ (2018). The Colorado civil rights statute defines disability as defined under the ADA. See COLO. REV. STAT. § 24-34-301(2.5) (2019). Accordingly, a separate analysis of the Colorado statute is omitted here. While the Colorado civil rights statute adopts the ADA definition of disability, neither the Supremacy Clause, nor other federal law requires a state 
definition of disability under the ADA, an employee "must (1) have a recognized impairment, (2) identify one or more appropriate major life activities, and (3) show the impairment substantially limits one or more of those activities." 180 The ADA defines major life activities broadly as "includ[ing], but . . . not limited to, caring for oneself, performing manual tasks, seeing, hearing, eating, sleeping, walking, standing, lifting, bending, speaking, breathing, learning, reading, concentrating, thinking, communicating, and working."

The question whether an employee, who needs to use medical cannabis, is a disabled person depends on the reason why that person needs to use medical cannabis. Take Brandon, for instance. He uses medical cannabis for excruciating pain caused by involuntary muscle spasms resulting from his paralysis. Taken together, Brandon's paralysis plus his crippling pain impairs several major life activities, such as walking, standing, lifting, bending, concentrating, thinking, communicating, and working.

Brandon could also show that he was qualified for the job because he held it for several years before he was fired not for incompetence, but for using medical cannabis. The question then is whether Brandon could show that he was fired because of his disability. This is a tricky question. Brandon wasn't fired so much because of his disability as he was fired because of the accommodation that made him a more productive worker. Accordingly, Brandon's real complaint is that Dish discharged him because it would not accommodate his disability.

Brandon's case for reasonable accommodation is similar to Barbuto v. Advantage Sales and Marketing, where (in the context of a wrongful termination and employment discrimination case) the employee, who used cannabis for Crohn's disease, tested positive for that substance. ${ }^{182}$ Relying on the Massachusetts civil rights statute, the Supreme Judicial Court of Massachusetts found that where the employee can show that he or she is a "handicapped person" as defined under state law, ${ }^{183}$ permitting the off-site

court's interpretation of federal law to yield to the federal court's interpretation, unless the interpretation is delivered by the United States Supreme Court. Cmty. Hosp. v. Fail, 969 P.2d 667, 672 (Colo. 1998).

180. Carter, 662 F.3d at 1142 (internal quotation marks and citation omitted); accord Tesone v. Empire Mktg. Strategies, 942 F.3d 979, 997 (10th Cir. 2019).

181. 42 U.S.C. $\S 12102(2)(A)(2018)$.

182. Barbuto v. Advantage Sales \& Mktg., L.L.C., 78 N.E.3d 37, 46 (Mass. 2017).

183. An Act for the Humanitarian Medical Use of Marijuana, ch. 369, §1, 2012 Mass. Acts 1583. 
use of marijuana during non-working hours may constitute a reasonable accommodation. ${ }^{184}$ The court further explained that the employer owed such employee a statutory obligation ${ }^{185}$ "to participate in the interactive process to explore with her whether there was an alternative." ${ }^{186}$ The employer also bears the burden of justifying why the accommodation (in this case using medical cannabis off-site and off-duty), if denied, presents an undue burden on the employer. ${ }^{187}$

\section{Summary}

The exceptions to at-will employment considered in Part II(B) are commonly available in most states. They serve as a basis for judicial protection of employees who use medical cannabis responsibly within the confines of state law. This serves several legislative and other public policies including the one stated under the ADA: "to assure equality of opportunity, full participation, independent living, and economic selfsufficiency for such individuals" ${ }^{\prime 188}$ with disabilities. Accordingly, we urge state judges to consider these exceptions in reviewing cases where an employer terminates the employment relationship because an otherwise productive employee was using medical cannabis lawfully under state law.

184. Barbuto, 78 N.E.3d at 46.

185. MASS. GEN. LAWS ch. 151B, § 4(16) (2018).

186. See Barbuto, 78 N.E.3d at 47.

187. See id. at 45 . The same analysis would occur under federal law:

As part of her prima facie case, the employee must show: (1) that she is a disabled person within the meaning of the ADA; (2) that she was otherwise qualified for her current position; (3) that she was terminated from that position because of her disability; (4) that she requested reasonable accommodation either within her current position or through transfer to a vacant position for which she was qualified; and (5) that, despite her request for reasonable accommodation by transfer to a vacant position, the employer continued to seek applicants for the vacant position or hired persons who possessed the disabled employee's qualifications. Once this showing has been made, the burden shifts to the employer to prove either undue hardship or that it made an offer of reasonable accommodation. At all times, the employee bears the ultimate burden of persuading the trier of fact that she has been the victim of illegal discrimination.

Cmty. Hosp. v. Fail, 969 P.2d 667, 672 (Colo. 1998). For an in-depth discussion of how these doctrines work in the context of drug addiction, see generally Samuel Brown Petsonk \& Anne Marie Lofaso, Working for Recovery: How the Americans with Disabilities Act and State Human Rights Laws Can Facilitate Successful Rehabilitation for Alcoholics and Drug Addicts, 120 W. VA. L. REV. 891 (2018). 188. 42 U.S.C. § 12101(a)(7) (2018). 


\section{PROPOSED IMPLEMENTATION OF ANTI-DISCRIMINATORY LANGUAGE IN COLO. CONST. ART. XVIII, SECTION 14 AND \\ COLO. CONST. ART. XVIII, SECTION 16}

\section{A. Overview}

In Part II(B), we explored several causes of actions under employment law that could protect employees like Brandon Coats, and we urged state judges to permit those causes of action. However, it is always safer to rely on strong constitutional or statutory language to protect society's most vulnerable. Below we have surveyed two state statutes to show how state legislatures, if so inclined, could further protect workers, like Brandon.

\section{B. Survey of State Statutes}

The following subsections review two states-Nevada and Oklahoma-that have expressly created statutory protections for employee use of medical cannabis.

\section{Nevada's Statute Regarding Medical Cannabis in Employment}

Nevada does not "[r]equire any employer to allow the medical use of marijuana in the workplace." ${ }^{189}$ However,

the employer must attempt to make reasonable accommodations for the medical needs of an employee who engages in the medical use of marijuana if the employee holds a valid registry identification card, provided that such reasonable accommodation would not: (a) Pose a threat of harm or danger to persons or property or impose an undue hardship on the employer; or (b) Prohibit the employee from fulfilling any and all of his or her job responsibilities. ${ }^{190}$

Nevada's inclusion of reasonable accommodations is an important step in protecting employees who hold valid registry identification cards for medical cannabis use. This allows employees, like Brandon Coats, whose medical cannabis use is essential to his job performance and enjoyment of life activities, to have an "equal opportunity not only to get

189. NEV. REV. STAT. § 453A.800(2) (2019).

190. NEV. REV. STAT. § 453A.800(3)(a)-(b) (2019). 
a job," but also to keep that job, and to "successfully perform [the] job tasks." $" 191$

Although Nevada has expressly included reasonable accommodation protection language in its statute, the text remains unclear as to whether employees or job applicants who use medical cannabis off-duty and test positive for marijuana on pre- or post-employment testing are protected. ${ }^{192}$ For this text, we review Oklahoma's medical cannabis statute.

\section{Oklahoma's Statute Regarding Medical Cannabis in Employment}

The Oklahoma Medical Marijuana and Patient Protection Act, which went into effect on August 30, 2019, ${ }^{193}$ prohibits an employer from refusing to "hire, discipline, [or] discharge... [an] employee" solely based on that "employee's status as a medical marijuana licensee." 194 The Act also prohibits an employer from refusing to "hire, discipline, [or] discharge... [an] employee" solely based on "a positive test for marijuana..." unless (1) the employee does not have a "valid medical marijuana license," (2) the employee "possesses, consumes or is under the influence of medical marijuana" while on the job, or (3) the employee works in a "safety-sensitive" position. ${ }^{195}$ The Act defines "safetysensitive" as "any job that includes tasks or duties that the employer reasonably believes could affect the safety and health of the employee performing the task or others" and includes a non-exhaustive list of examples. ${ }^{196}$

191. Office of Disability Emp't Policy, Accommodations, U.S. DEP'T LAB., https://www.dol.go v/odep/topics/accommodations.htm [https://perma.cc/H77L-H8QV].

192. See NEV. REV. STAT. § 453A.800(3) (2019).

193. Fred Morgan, What You Need to Know About the Unity Bill, STATE CHAMBer OKLA.: IN THE NEwS (Aug. 26, 2019), https://www.okstatechamber.com/blog/post/what-you-need-to-knowabout-the-unity-bill [https://perma.cc/Z9JP-5579].

194. OKLA. STAT. tit. 63, $\S 427.8(\mathrm{H})(1)$ (Supp. 2019).

195. OKLA. STAT. tit. 63, § 427.8(H)(2)(a)-(c) (Supp. 2019).

196. OKLA. STAT. tit. 63, $\S 427.8(\mathrm{~K})(1)$ (Supp. 2019). "Safety-sensitive" jobs include but are not limited to

any of the following: (a) the handling, packaging, processing, storage, disposal or transport of hazardous materials; (b) the operation of a motor vehicle, other vehicle, equipment, machinery or power tools; (c) repairing, maintaining or monitoring the performance or operation of any equipment, machinery or manufacturing process, the malfunction or disruption of which could result in injury or property damage; (d) performing firefighting duties; (e) the operation, maintenance or oversight of critical services and infrastructure including, but not limited to, electric, gas, and water utilities, power generation or distribution; (f) the extraction, compression, processing, manufacturing, handling, packaging, storage, disposal, treatment or transport of 
This Act accomplishes two important goals. ${ }^{197}$ "One, it respects the will of the voters following the legalization of marijuana in Oklahoma. ${ }^{198}$ Two, it provides much-needed clarity for employers and business owners" on the law's role in protecting their legitimate managerial and business concerns. ${ }^{199}$

\section{Proposed Language}

We provide the following protective language so that citizens may use it as a ballot initiative to encourage or compel legislators to amend their state constitutions and adopt protective provisions for employees who are registered medical cannabis patients or who are designated caregivers of registered patients. The focus here is on changing the language in the Colorado Constitution, but the language serves as an example for future use in other states as well. Incorporating this language will protect employers from litigation, protect employees from discrimination, balance the competing interests of employers and employees, prevent individuals with debilitating conditions from having to choose between a life of pain (but no job) and gainful employment (but excruciating pain), and increase employment options for both employers and employees. The following language is grounded in the text of the Nevada ${ }^{200}$ and Oklahoma ${ }^{201}$ statutes.

The proposed amendments would require employers to provide reasonable accommodations for registered medical cannabis patients and disallow discrimination based solely on an employee's status as a registered medical cannabis user or registered caregiver, subject to some included exceptions.

potentially volatile, flammable, combustible materials, elements, chemicals or any other highly regulated component; $(\mathrm{g})$ dispensing pharmaceuticals; $(\mathrm{h})$ carrying a Id.

firearm, or (i) direct patient care or direct child care.

197. Morgan, supra note 193.

198. Id.

199. Id.

200. Nev. Rev. StAT. § 453A.800 (2017).

201. OKLA. STAT. tit. 63, § 427.8 (Supp. 2019). 


\title{
1. Amendment to Article XVIII, Section 14 of Colorado's State Constitution
}

\author{
AMENDMENT NO. \\ . Amend Colo. Const. Art. XVII, Section 14 by \\ replacing $10(\mathrm{~b})$ with the following:
}

(10)(b) No employer may refuse to hire, discipline, discharge or otherwise penalize an applicant or employee based solely on past or present status as a registered medical marijuana patient or designated caregiver of a medical marijuana patient unless: (1) it would cause the employer to lose licensing-related benefits or funding under federal law, (2) the employer has good faith belief that the employee possesses, consumes, or is under the influence of medical marijuana on company property or during work hours, (3) the employer has a good faith belief that the employee was impaired or using marijuana while working on company property during work hours, but the employee must be given a chance to challenge the basis for the determination, or the position is one involving safety-sensitive job duties, as such term is defined in 10(c) of this section.

(c) As used in this section: "Safety-sensitive" means any job that includes tasks or duties that the employer reasonably believes that could affect the safety and health of the employee performing the task or others including, but not limited to, any of the following:

(1) the handling, packaging, processing, storage, disposal or transport of hazardous materials;

(2) the operation of a motor vehicle, other vehicle, equipment, machinery or power tools;

(3) repairing, maintaining, or monitoring the performance or operation of any equipment, machinery or manufacturing process, the malfunction or disruption of which could result in injury or property damage;

(4) performing firefighting duties;

(5) the operation, maintenance or oversight of critical services and infrastructure including, but not limited to, electric, gas, and water utilities, power generation or distribution;

(6) the extraction, compression, processing, manufacturing, handling, packaging, storage, disposal, treatment or transport of potentially volatile, flammable, combustible 
materials, elements, chemicals or any other highly regulated component;

(7) dispensing pharmaceuticals;

(8) carrying a firearm; or

(9) direct patient care or direct childcare.

(d) Employers must try to make reasonable accommodations for registered medical marijuana patients' off-site, off-duty use of marijuana as long as it would not pose a safety threat to people or property, cause an undue hardship, or prevent the employee from fulfilling his or her job responsibilities.

\section{Amendment to Article XVIII, Section 14 of Colorado's State Constitution}

AMENDMENT NO. __ Amend Colo. Const. Art. XVIII, Section 16 by replacing 6(a) with the following:

(6)(a) Nothing in this section is intended to require an employer to permit or accommodate the recreational use, consumption, possession, transfer, display, transportation, sale or growing of marijuana in the workplace or to affect the ability of employers to have policies restricting the use of recreational marijuana by employees.

\section{Reasons Why the Proposed Amendments Should Be Adopted}

Without the implementation of the above constitutional (or statutory) amendments, what happened to Brandon Coats would continue to happen to every registered medical cannabis patient whose ability to perform essential life activities depends on medical cannabis use. Brandon Coats, a registered medical cannabis patient, was fired from his job for violating the company's zero-tolerance drug policy when he tested positive for THC after a random drug test. ${ }^{202}$ Brandon is now unemployed and cannot find work. ${ }^{203}$ He must now choose between using medical cannabis to manage his debilitating symptoms or living with the painful symptoms that

202. Coats v. Dish Network, L.L.C., 2013 COA 62, ๆ 4, 303 P.3d 147, 149 (Colo. App. 2013), (citing complaint allegations), aff' $d, 2015 \mathrm{CO} 44$, ๆ 5, 350 P.3d 849, 850 (Colo. 2015). 
accompany his condition as a quadriplegic just for a chance at employment. ${ }^{204}$

For another take on the position of employees who rely on the use of medical cannabis to sustain essential life activities, such as maintaining a job, imagine the following: It is 2020 and you currently live in Colorado and work as an accountant at a small accounting firm. You have just been diagnosed with cancer at the young age of 30 . You start chemotherapy and your hair begins to fall out, you become fatigued, start to vomit until there is nothing left in your stomach, suffer nerve and muscle problems, start to lose your sense of taste and appetite, and fall into a state of depression. ${ }^{205}$ Your physician recommends that you try medical cannabis to manage your symptoms. ${ }^{206}$ Medical cannabis helps you immensely, enough so that you can return to work. A few weeks after you return to work, your boss fires you after a drug test comes back positive for THC. You lose your job, your income, and your health insurance. You can no longer afford medical cannabis to manage your symptoms. You can no longer afford chemotherapy to stay alive. You desperately search for employment, but employers refuse to hire you because of your medical cannabis usage. You now must choose between using medical cannabis to manage your symptoms or trying to live with the awful symptoms that accompany cancer to gain employment. This example, along with Brandon Coats's story, illustrate precisely why Colorado, and other states, should implement the proposed statutory language by amending their constitutions.

To date, the Colorado Court of Appeals has dismissed employees' claims for employment discrimination and wrongful termination where the employee was terminated for medical cannabis use. ${ }^{207}$ As a result, medical cannabis patients in Colorado are left with the following impossible Hobson's choice: (1) give up cannabis and continue to suffer but lawfully pursue a career and the possibility of living independently (assuming the

204. Id.

205. Diana Brinkley, Emotional Distress During Cancer Chemotherapy, 286 BRIT. MED. J. 663, 663-64 (1983).

206. Medical marijuana can provide relief of cancer-related symptoms like pain, nausea, and inflammation. David Bienenstock, A Patient's Guide to Using Cannabis for Cancer, LEAFLY (Feb. 6, 2019), https://www.leafly.com/news/health/how-to-use-medical-marijuana-for-cancer [https://perma .cc/MJR2-4BBQ]. "Some research has even shown that some cannabis compounds may slow cancer growth and shrink tumors. Cannabis can also elevate your mood at critical moments, and even help you psychologically come to grips with the difficult times ahead." Id.

207. See, e.g., Coats v. Dish Network, L.L.C., 2013 COA 62, 303 P.3d 147 (Colo. App. 2013). 
pain does not prevent the employee from being productive at work) or (2) continue to use cannabis but give up the right to pursue a career and thus become dependent on family members or the government for survival. In this way, the current state of Colorado law $^{208}$ places employers' concerns-legitimate or illegitimate - above employees' interests.

The statutory amendments proposed would balance employee and employer interests. The amendments would provide a private right of action for registered medical cannabis patients, like Brandon Coats, and would also allow patients to "bring successful wrongful termination claims" based on a "clear, statutory public policy."209 The proposed amendment would still protect an employer's interest through the inclusion of exceptions. ${ }^{210}$ Article XVII 10(b)(1) provides an exception that would ensure that the employer's funds under federal law would not be at risk. ${ }^{211}$ Article XVII 10(b)(2) and 10(b)(3) ensure that an employer's job productivity would not fall to a loss. ${ }^{212}$ It further ensures an employer's ability to protect itself from third-party liability in the case of a job-related incident related to the use of medical cannabis. ${ }^{213}$

In addition to balancing these interests, the amendment would greatly help Colorado's economy. Colorado has been a leader in the crusade to decriminalize and legalize cannabis. ${ }^{214}$ Colorado was the seventh state to legalize medical cannabis, ${ }^{215}$ and the first state to legalize recreational use of marijuana and to regulate the production and distribution of marijuana for adults. ${ }^{216}$ Accordingly, Colorado already raises enormous revenue from marijuana sales, runs a market serving as a model for other states, and as of August, 2019, had 81,035 patients with active medical cannabis

208. See COLO. CONST. art. XVIII, § 16.

209. Elizabeth Rodd, Light, Smoke, and Fire: How State Law Can Provide Medical Marijuana Users Protection From Workplace Discrimination, 55 B.C. L. REV. 1759, 1793 (2014).

210. Id.

211. Id.

212. Id.

213. Id.

214. See Andrew A. Monte et. al., The Implications of Marijuana Legalization in Colorado, 313 [J]AMA 241 (2015).

215. Sam Kamin, Colorado Marijuana Regulation Five Years Later: Have We Learned Anything At All?, 96 DENVER L. REV. 221, 224 (2019); see Pacula \& Smart, supra note 98.

216. See Colo. DeP'T. Pub. Health \& EnV'T, Medical Marijuana Registry Program UPDATE (AS OF JANUARY 31, 2009) (on file with Seattle University Law Review). 
registrations. ${ }^{217}$ Colorado has even recently passed a bill allowing the delivery of marijuana products to customers. ${ }^{218}$

In summary, it is highly unlikely that the voters and legislators of Colorado wish to make registered medical cannabis patients choose unemployment (and lost health insurance and dependence) over continued use of a state-sanctioned substance for managing debilitating medical conditions. Colorado authorizes the use of medical cannabis; it should, therefore, provide protections for those who use it. The purpose of these medical cannabis statutes - to promote the "health, safety, and welfare of citizens" ${ }^{219}$ - is frustrated without the proposed amending language. ${ }^{220}$ It also frustrates the cost-savings and revenue producing goals of legalizing cannabis because those who lose their jobs for using medical cannabis may become a public burden. As one commentator explained, "It is high time that states protect disabled employees from suffering employment discrimination due to their use of a state-sanctioned, therapeutic remedy."221

\section{ACCOMMODATIONS FOR EMPLOYEES LAWFULLY USING MEDICAL CANNABIS}

\section{A. Overview}

Employers may struggle with implementing the proposed language requiring them to reasonably accommodate registered medical cannabis patients. Change is often difficult. This Part provides helpful ideas for reasonable accommodations in the workforce that benefit both employers and employees.

Employers providing work accommodations for registered medical cannabis patients can choose between a vast array of options such as

217. Robert M. Kline, Courts Are Siding with Employees Who Use Medical Marijuana, NAT'L L. REV. (June 19, 2019), https://www.natlawreview.com/article/courts-are-siding-employees-whouse-medical-marijuana [https://perma.cc/5AVL-E428]; Matej Mikulic, Colorado Current Active Medical Marijuana Patients 2017-2019 By Month, STATISTA (Oct. 10, 2019),

https://www.statista.com/statistics/586495/medical-marijuana-patients-colorado-current-by-month/ [https://perma.cc/XY25-KTDJ].

218. H.B. 19-1234, 72d Gen. Assemb., Reg. Sess. (Colo. 2019).

219. Rodd, supra note 209, at 1766.

220. See id. at $1793-94$

221. Id. at 1794. 
modifying employees' job duties, ${ }^{222}$ adjusting work schedules to accommodate medical needs, ${ }^{223}$ transferring the employee to a non-safetysensitive position, modifying work rule policies (e.g., shifting from "zerotolerance drug testing" to "zero-tolerance drug-free workplace"), and allowing the employee to use "marijuana products that have low tetrahydrocannabinol (THC)."224

\section{B. Exceptions Included in Proposed Amendment to Colo. Const. Art. XVIII, Section 14}

Employers may refuse to hire or take adverse action against employees in circumstances where the position is safety-sensitive, the employee is using marijuana on-site during working hours, or a registered employee's off-site medical marijuana use would cause the employer to lose licensing-related benefits or funding under federal law. Employers should, however, narrowly construe these exceptions. ${ }^{225}$

\section{Why the Safety-Sensitive Position Exception is Needed}

An individual in a safety-sensitive position, if impaired by marijuana in the workplace, could endanger the health and well-being of themselves colleagues and the general public. The proposed amendment recognizes that danger and specifically carves out an exception for safety-sensitive positions.

Suppose that Brandon Coats obtains a position as a mining site supervisor. His job duties include monitoring the performance or operation of any equipment, machinery, or manufacturing process, the malfunction or disruption of which could result in injury or property damage. Brandon's new position requires him to be exceptionally alert in his response and judgments. Brandon still uses medical cannabis and remains a registered medical cannabis patient. The use of such causes Brandon to

222. Allen Smith, Some Employers Accommodate Medical Marijuana Users, SHRM (Apr. 18, 2017), https://www.shrm.org/resourcesandtools/legal-and-compliance/employment-law/pages/accom modating-medical-marijuana-users.aspx [https://perma.cc/RY6X-V8PM].

223. Office of Disability Emp't Policy, supra note 191.

224. Alonzo Martinez, Marijuana Accommodations In The Workplace: Your Employees Are Smoking Pot-Now What?, FORBES (Oct. 1, 2019), https://www.forbes.com/sites/alonzomarti nez/2019/10/01/marijuana-accommodations-in-the-workplace-your-employees-are-smoking-potnow-what/\#a1c7ade507d1 [https://perma.cc/TPC8-XJCB].

225. Courtney Bru, Employers May Soon Rely on 'Safety-Sensitive' Exceptions to Medical Marijuana Use, JDSUPRA (Apr. 9, 2019), https://www.jdsupra.com/legalnews/employers-may-soonrely-on-safety-63790/ [https://perma.cc/G844-MS3U]. 
suffer some impaired judgment, distorted perceptions, and memory impairment, ${ }^{226}$ all traits inconsistent with Brandon's new job duties.

This illustration exemplifies the concern surrounding marijuana use in safety-sensitive positions and the grave need for the proposed exception. ${ }^{227}$ To utilize this safety-sensitive position exception, the employer should confirm, and continuously ensure, that the job duties of a particular position fall under the safety-sensitive position examples. ${ }^{228}$ The employer should then modify its policies to include the safetysensitive position exception, making sure to incorporate the language from the proposed amendment. ${ }^{229}$ Prior to modification of policies, the employer should provide proper notice ${ }^{230}$ to employees who are subject to the policy changes. ${ }^{231}$ The employer should regularly check for any modifications that would change a safety-sensitive position to a nonsafety-sensitive position and make sure that their policies are up-to-date with current law before taking any adverse actions against employees.

\section{Why the Employee Use of Medical Cannabis During Work Hours Exception is Needed}

Imagine a scenario where Brandon Coats, a telephone customer service representative for Dish Network, comes to work with cannabis. While at work, Brandon begins to smoke the cannabis. His co-worker, at the desk beside him, inhales the cannabis that Brandon is smoking. This co-worker just happens to have an unknown cannabis allergy. The coworker grows wheezy as she chokes on the smoke, her nose runs, her eyes water, and her face swells. ${ }^{232}$ Or worse yet, that co-worker has a safetysensitive position, the execution of which is now endangered by cannabis inhalation. Although Brandon is a registered medical cannabis patient, his

226. Nora D. Volkow, Letter from the Director, NAT'L INST. ON DRUG ABUSE (Apr. 2020), https://www.drugabuse.gov/publications/research-reports/marijuana/letter-director [https://perma.cc/8U5W-WG8K].

227. See generally Francesca Liquori, The Effects of Marijuana Legalization on Employment Law, 1 NAGTRI J. 2, 4, 12 (2016).

228. Id. Employers may soon rely on 'safety-sensitive' exceptions to medical marijuana use. Bru, supra note 225.

229. Liquori, supra note 227, at 12.

230. Adams Cnty. Sch. Dist. No. 50 v. Dickey, 791 P.2d 688, 693 (Colo. 1990) (citing In re Certified Question, 432 Mich. 438, 441 (Mich. 1989)).

231. Id. at 696 .

232. Marijuana Cannabis Allergy, AM. ACAD. Allergy Asthma \& IMMUnOlOGY, https:// www.aaaai.org/conditions-and-treatments/library/allergy-library/marijuana-cannabis-allergy [https:// perma.ce/W5XJ-CLAC]. 
use of cannabis during work hours has inadvertently caused adverse effects. This situation is a prime example as to why the employee use of medical cannabis during work hours exception is needed.

If the employer knows that an employee is using marijuana during working hours, or that an employee is impaired during working hours, the employer could potentially be sued for negligence or even wrongful death if its employee injures or kills a person while performing descriptive job duties. An employee's use of marijuana during working hours could affect other employees, as shown in the above example. If one employee uses cannabis during work hours, that employee may expose others to the substance or even share the cannabis with others, exasperating the employer's potential liability. Furthermore, some employees may not wish to be around cannabis (just as many do not wish to be around cigarette smoke) and may take issue with another employee using cannabis while at work. An employer needs to foster a good work environment not only for increasing job productivity but also for fostering employee morale and worker satisfaction for all employees. Allowing marijuana during work hours could have an adverse impact on that objective.

Employers should be careful to use this exception only when they have a good-faith belief that the employee is using the medical cannabis while on duty or on site. Distinguishing the cause and timing of an employee's impairment is a difficult task. ${ }^{233}$ Traces of cannabis "can persist in a person's body for as long as 30 days after it was last used." 234 This causes difficulties in determining whether the employee is impaired from using cannabis during the work hours that day, at home the night before, or at home ten days before that shift. ${ }^{235}$ If an employer uses this exception, and acts adversely against an employee who tests positive for cannabis, that employer may be subject to liability because proving the time of impairment is challenging. ${ }^{236}$

233. Kline, supra note 217.

234. Id.

235. Id.

236. Id.; see also Dale L. Deitchler \& Wendy M. Krincek, Weed and Work: Are Marijuana Users the Newest Protected Class?, NEV. LAw., Feb. 2018, at 10, 13 ("[T] here is no universally accepted method of proving whether, or to what extent, an individual is impaired by marijuana, because there is no consensus as to what THC concentrate correlates to impairment. Drug tests do not measure impairment. Therefore, taking adverse action against an employee creates a risk of violating laws. Meanwhile, not taking action and allowing an employee that could be impaired to continue to work, particularly in safety-sensitive positions, creates risk of its own."). 
Before taking adverse actions against employees under the employee use of medical cannabis during work hours exception, employers should review their policies, make sure those policies are current with valid law, provide the needed notice to all employees, and consult with legal counsel. ${ }^{237}$

\section{Call to Colorado to Protect Its Workers}

Colorado has been a leader in cannabis legalization. Medical cannabis is part of its political landscape. It is time that Colorado provides protection for employees that are lawfully using a drug that has been state-legalized since 2011. The proposed language to amend the Colorado Constitution will protect employers from litigation, protect employees from discrimination, balance competing interests of employers and employees, stop those with debilitating conditions from having to choose between a life of pain and employment, and increase employment options for both employers and employees.

\section{CONCLUSION}

This Article's first author, a member of Gen X, grew up in the 1970s and $1980 \mathrm{~s}$ - a time when cannabis was considered - rightly or wrong - a gateway drug that invariably led to increased use of more dangerous drugs such as cocaine, heroin, methamphetamines (speed) and methaqualone (Quaaludes). By the time this Article's second author (a Millennial) was born, cannabis was much more accepted as a medicinal rather than illicit substance. It is those experiences that have framed our discussion.

Work law in the United States has trended toward increased employee protection during the latter half of the twentieth and the early twenty-first centuries. These increased protections are particularly true for individuals with disabling conditions who, with some accommodation, can lead productive lives. Liberalizing laws to permit workers to use medical cannabis fits this trend.

To be sure, work laws are typically a balancing act among various interests - especially those of the employer, the worker, co-workers, and the public. But protecting the jobs of chronically ill workers to use medical cannabis under a doctor's supervision, coupled with the exceptions outlined in this article, meet the concerns of all interested parties.

237. Kline, supra note 218. 
Resistance to these laws can be explained primarily by reference to early twentieth-century cannabis demonization. That reputation has lasted for over a century now. But renewed interest in developing cannabis's medicinal uses has created a cognitive dissidence - a tension between the belief that cannabis is a dangerous, gateway drug and the ever-increasing scientific proof that cannabis can serve useful medicinal purposes that can transform a person's life from one of disability to one of social productivity and personal fulfillment. This is not to say that cannabis does not have side-effects. The use of most medical substances can have undesirable outcomes or unintended consequences. It is for this reason that we recommend certain exceptions to these job-security regulations. Accordingly, re-evaluation of decisionmakers' historical assessment of cannabis is prudent in light of evidence that decisionmakers may have had political agendas and where medical science has evolved. 
[Vol. 43:955

\section{ADDENDUM}

\begin{tabular}{|c|c|c|c|c|}
\hline State & $\begin{array}{c}\text { Cannabis } \\
\text { Legality: } \\
\text { Illegal / } \\
\text { Medical / } \\
\text { Legal }\end{array}$ & $\begin{array}{l}\text { Are Employers } \\
\text { Required to } \\
\text { Accommodate } \\
\text { Medical Cannabis } \\
\text { Use? }\end{array}$ & $\begin{array}{l}\text { Are Employers } \\
\text { Prohibited In } \\
\text { Discriminating } \\
\text { Against Medical } \\
\text { Cannabis Use? }\end{array}$ & Citations \\
\hline Alabama & Illegal & N/A & $\mathrm{N} / \mathrm{A}$ & $\begin{array}{c}\text { ALA. CODE } \S \S 13 \mathrm{~A}- \\
12-211 \text { to } 13 \mathrm{~A}-12- \\
214(2018) .\end{array}$ \\
\hline Alaska & Legal & $\begin{array}{c}\text { No. AlaSKA StAT. } \S \\
17.37 .040(\mathrm{~d})(1) .\end{array}$ & $\begin{array}{l}\text { No. ALASKA } \\
\text { STAT. } \S \\
17.38 .220(\mathrm{a})) .\end{array}$ & $\begin{array}{c}\text { ALASKA STAT. } \S \S \\
17.37 .010-17.37 .080 \\
(2010) ; I d . \S \S \\
17.38 .010-17.38 .050 \\
(2015) .\end{array}$ \\
\hline Arizona & Medical & $\begin{array}{c}\text { No. ARIZ. REV. } \\
\text { STAT. §36- } \\
2814(\mathrm{~A})(3) \text { and (B). }\end{array}$ & $\begin{array}{l}\text { Yes. ARIZ. REV. } \\
\text { STAT. §36-2813. }\end{array}$ & $\begin{array}{c}\text { ARIZ. REV. STAT. } \S \S \\
36-2801 \text { to } 36-2819 \\
(2019) .\end{array}$ \\
\hline Arkansas & Medical & $\begin{array}{l}\text { No. ARK. CONST. } \\
\text { Amend. XCVIII, § } \\
\text { 6(b)(2). }\end{array}$ & $\begin{array}{l}\text { No. ARK. CONST. } \\
\text { Amend. XCVIII, } \S \\
\text { 3(f)(3)(A). }\end{array}$ & $\begin{array}{l}\text { ARK. CONST. art. } \\
\text { XCVIII, } \S \S 1-25 .\end{array}$ \\
\hline California & Legal & $\begin{array}{c}\text { No. CAL. HEALTH \& } \\
\text { SAFETY CODE } \S \\
\text { 11362.785; Ross v. } \\
\text { RagingWire } \\
\text { Telocommunications, } \\
\text { Inc., 42 Cal. 4th 920 } \\
\text { (2008). }\end{array}$ & $\begin{array}{c}\text { No. CAL. HEALTH } \\
\text { \& SAFETY CODE } \\
\S \S 11362.5 ; \text { Ross } \\
\text { v. RagingWire } \\
\text { Telocommunicatio } \\
\text { ns, Inc., } 42 \text { Cal. } \\
\text { 4th } 920 \text { (2008). }\end{array}$ & $\begin{array}{c}\text { CAL. HEALTH \& } \\
\text { SAFETY CODE } \S \S \\
\text { 11362.5, 11362.7- } \\
11362.9 \text { (1996); CAL. } \\
\text { HEALTH \& SAFETY } \\
\text { CODE } \S \S 11362.1- \\
\text { 11362.45 (2017); } \\
\text { Ross v. RagingWire } \\
\text { Telecomm., Inc., 174 } \\
\text { P.3d } 200 \text { (Cal. 2008). }\end{array}$ \\
\hline Colorado & Legal & $\begin{array}{l}\text { No. COLO. CONST. } \\
\text { art. XVIII, } \S 16(a) .\end{array}$ & $\begin{array}{l}\text { No. COLO. CONST. } \\
\text { art. XVIII, } \S 16(a) .\end{array}$ & $\begin{array}{l}\text { COLO. CONST. art. } \\
\text { XVIII, } \S \S 14,16 ; \\
\text { Coats v. Dish } \\
\text { Network, LLC., } 350 \\
\text { P.3d 849 (Colo. } \\
\text { 2015); Curry } \\
\text { v. MillerCoors, Inc., } \\
\text { No. 12-cv-02471- } \\
\text { JLK, 2013 WL } \\
\text { 4494307 (D. Colo. } \\
\text { Aug. 21, 2013). }\end{array}$ \\
\hline Connecticut & Medical & $\begin{array}{c}\text { No. CONN. GEN. } \\
\text { STAT. } \S 31-51 y(b) .\end{array}$ & $\begin{array}{l}\text { No. Co CONN. } \\
\text { GEn. STAT. } \S \S \\
21 \mathrm{a}-408 \mathrm{p}(\mathrm{b})(3) .\end{array}$ & $\begin{array}{c}\text { CONN. GEN. STAT. } \S \\
31-51 \mathrm{y}(\mathrm{b})(2011) ; \S \S \\
21 \mathrm{a}-408 \text { to } 21 \mathrm{a}-408 \mathrm{v} \\
(2017) .\end{array}$ \\
\hline Delaware & Medical & $\begin{array}{c}\text { No. DEL. CODE ANN. } \\
\text { tit. } 16 \S 4907 \mathrm{~A} .\end{array}$ & $\begin{array}{l}\text { No. DEL. CODE } \\
\text { ANN. tit. } 16 \S \\
4905 \mathrm{~A}(\mathrm{a})(3) .\end{array}$ & $\begin{array}{c}\text { DEL. CODE ANN. tit. } \\
16, \S \S 4901 \mathrm{~A}-4928 \mathrm{~A} \\
(2011) .\end{array}$ \\
\hline
\end{tabular}




\begin{tabular}{|c|c|c|c|c|}
\hline $\begin{array}{l}\text { District of } \\
\text { Columbia }\end{array}$ & Legal & $\begin{array}{l}\text { No. D.C. CODE § 48- } \\
\text { 904.01(a)(1C). }\end{array}$ & $\begin{array}{l}\text { No. D.C. CODE } \S \\
7-1671.03(d)(1) .\end{array}$ & $\begin{array}{c}\text { D.C. CODE } \S \S 7- \\
\text { 1671.01 to 7-1671.13 } \\
\text { (2017); D.C. CODE } \S \\
\text { 48-904.01 (2015). }\end{array}$ \\
\hline Florida & Medical & $\begin{array}{l}\text { No. FLA. STAT. } \S \\
381.986(15)(\mathrm{b}) .\end{array}$ & $\begin{array}{l}\text { No. FLA. STAT. } \S \\
381.986(15)(a) .\end{array}$ & $\begin{array}{c}\text { FLA. STAT. § } 381.986 \\
(2019) .\end{array}$ \\
\hline Georgia & Medical & $\begin{array}{l}\text { No. GA. CODE ANN. } \\
\S 16-12-191(\mathrm{~g}) .\end{array}$ & N/A & $\begin{array}{c}\text { GA. CODE ANN. § } \\
16-12-191(\mathrm{~g})(2019) .\end{array}$ \\
\hline Hawaii & Medical & $\begin{array}{l}\text { No. HAW. REV. } \\
\text { STAT. § 329- } \\
122(\mathrm{e})(2)(\mathrm{B}) \text {. }\end{array}$ & N/A & $\begin{array}{c}\text { HAW. REV. STAT. } \S \S \\
\text { 329-121 to 329-128 } \\
\text { (2018). }\end{array}$ \\
\hline Idaho & Illegal & N/A & N/A & $\begin{array}{c}\text { IDAHO CODE } \$ \S 37- \\
2701 \text { to } 37-2751 \\
\text { (2015) }\end{array}$ \\
\hline Illinois & Legal & $\begin{array}{l}\text { No. } 410 \text { ILL. COMP. } \\
\text { STAT. } § 130 / 50 .\end{array}$ & $\begin{array}{c}\text { No. } 410 \text { ILL. } \\
\text { COMP. STAT. } \S \\
130 / 40 .\end{array}$ & $\begin{array}{l}410 \text { ILL. COMP. } \\
\text { STAT. } 130 / 30 \text { to } \\
130 / 50(2019) .\end{array}$ \\
\hline Indiana & Illegal & N/A & N/A & $\begin{array}{c}\text { IND. CODE § 35-48- } \\
4-11 \text { (2018). }\end{array}$ \\
\hline Iowa & Illegal & N/A & N/A & $\begin{array}{c}\text { IOWA CODE } \S \S \\
\text { 124.101-124.602 } \\
(2017) ; \text { IOWA CODE } \\
\S \S 205.11-205.13 \\
(2007) .\end{array}$ \\
\hline Kansas & Illegal & N/A & N/A & $\begin{array}{c}\text { KAN. STAT. } \\
\text { ANN. } \$ \$ 21-5701 \text { to } \\
21-5717(2019) .\end{array}$ \\
\hline Kentucky & Illegal & N/A & N/A & $\begin{array}{l}\text { KY. REV. STAT. ANN. } \\
\S \S 218 \mathrm{~A} .005- \\
\text { 218A.1452 (2011). }\end{array}$ \\
\hline
\end{tabular}




\begin{tabular}{|c|c|c|c|c|}
\hline Louisiana & Medical & N/A & N/A & $\begin{array}{c}\text { LA. STAT. } \S \S \\
\text { 40:1046-40:1049 } \\
(2019) .\end{array}$ \\
\hline Maine & Legal & $\begin{array}{l}\text { No. ME. STAT. tit. 22, } \\
\quad \S 2426(2)(B) .\end{array}$ & $\begin{array}{l}\text { Yes. ME. STAT. tit. } 22 \text {, } \\
\S 2430-\mathrm{C}(3) \text { and ME. } \\
\text { STAT. tit. 28-B, } \S 112 .\end{array}$ & $\begin{array}{l}\text { ME. STAT. tit. 22, } \\
\S \S 2421 \text { to } 2430- \\
\text { B (2010); ME. } \\
\text { STAT. tit. } 7, \S \S \\
2441-2455 \\
\text { (2018); ME. } \\
\text { STAT. tit. } 28-B, \\
\S \S 10-1504 .\end{array}$ \\
\hline Maryland & Medical & $\mathrm{N} / \mathrm{A}$ & N/A & $\begin{array}{c}\text { MD. HEALTH- } \\
\text { GEN. CODE ANN. } \\
\S 33 \text { (2015). }\end{array}$ \\
\hline Massachusetts & Legal & $\begin{array}{l}\text { No. MASS. GEN. } \\
\text { LAWS Ch. 94G } \S \\
\text { 2(e); } 935 \text { MASS. } \\
\text { CODE REGS. § } \\
501.840(2)(d) .\end{array}$ & $\mathrm{N} / \mathrm{A}$ & $\begin{array}{c}\text { MASS. GEN. } \\
\text { LAWS Ch. 94I, } \\
\S \S 1-8 \text { (2018); } \\
\text { MASS. GEN. } \\
\text { LAWS Ch. 94G, } \\
\S \S 1-21 \text { (2017); } \\
935 \text { MASS. CODE } \\
\text { REGS. } \S \S \\
501.001- \\
\text { 501.900; Barbuto } \\
\text { v. Advantage } \\
\text { Sales \& Mktg, } \\
\text { L.L.C., 78 } \\
\text { N.E.3d 37 (Mass. } \\
\text { 2017). }\end{array}$ \\
\hline Michigan & Legal & $\begin{array}{l}\text { No. MicH. COMP. } \\
\text { LAWS } \S \S \\
333.26427(\mathrm{c})(2) \text { and } \\
333.27954 .\end{array}$ & $\begin{array}{c}\text { No. MiCH. COMP. } \\
\text { LAWS } \S \S 333.26424 \\
\text { and } 333.27954 ; \text { see } \\
\text { Eplee v. City of } \\
\text { Lansing, 2019 Mich. } \\
\text { App. LEXIS } 1320 \\
\text { (Mich. Ct. App. Feb. } \\
\text { 19, 2019); Casias v. } \\
\text { Wal-Mart Stores, Inc., } \\
\text { 695 F.3d 428 (2012); } \\
\text { but also see Braska v. } \\
\text { Challenge Mfg. Co., } \\
\text { 861 N.W.2d 289 } \\
\text { (Mich. Ct. App., } \\
\text { 2014). }\end{array}$ & $\begin{array}{c}\text { MICH. COMP. } \\
\text { LAWS } \S \S \\
333.26421- \\
333.26430 \\
\text { (2008); MicH. } \\
\text { COMP. LAWS } \S \S \\
\text { 333.27951- } \\
\text { 333.27967 } \\
\text { (2018); Eplee v. } \\
\text { City of Lansing, } \\
\text { 935 N.W.2d 104 } \\
\text { (Mich. Ct. App. } \\
\text { 2019); Casias v. } \\
\text { Wal-Mart Stores, } \\
\text { Inc., 695 F.3d } \\
\text { 428 (6th Cir. } \\
\text { 2012); Braska v. } \\
\text { Challenge Mfg. } \\
\text { Co., 861 N.W.2d } \\
\text { 289 (Mich. Ct. } \\
\text { App. 2014). }\end{array}$ \\
\hline
\end{tabular}




\begin{tabular}{|c|c|c|c|c|}
\hline Minnesota & Medical & $\begin{array}{c}\text { No. MinN. STAT. } \$ \\
152.32 \text { subd. } 3(\mathrm{c})(2) .\end{array}$ & $\begin{array}{l}\text { Yes. MINN. STAT. } \S \\
152.32 \text { subd. } 3(\mathrm{c}) .\end{array}$ & $\begin{array}{c}\text { MINN. STAT. \$§ } \\
152.21-152.37 \\
(1997) .\end{array}$ \\
\hline Mississippi & Illegal & N/A & N/A & $\begin{array}{c}\text { MISS. CODE } \\
\text { ANN. } \S \S 41-29- \\
101 \text { to } 41-29-191 \\
\text { (2013). }\end{array}$ \\
\hline Missouri & Medical & $\begin{array}{l}\text { No. MO. CONST. art. } \\
\text { XIV, } \S 7(1)(d) .\end{array}$ & N/A & $\begin{array}{l}\text { Mo. CONST. art. } \\
\text { XIV, } \S 1-9 .\end{array}$ \\
\hline Montana & Medical & $\begin{array}{c}\text { No. MONT. CODE } \\
\text { ANN. § 50-46- } \\
\text { 320(4)(b); Johnson v. } \\
\text { Columbia Falls } \\
\text { Aluminum Co., } 213 \\
\text { P.3d 789 (Mont. } \\
\text { 2009). }\end{array}$ & $\begin{array}{c}\text { No. MONT. CODE } \\
\text { ANN. } \S 50-46-320(5) .\end{array}$ & $\begin{array}{c}\text { MONT. CODE } \\
\text { ANN. } \S \S 50-46- \\
301 \text { to 50-46-345 } \\
\text { (2016); Johnson } \\
\text { v. Columbia } \\
\text { Falls Aluminum } \\
\text { Co., } 213 \text { P.3d } \\
789 \text { (Mont. } \\
\text { 2009). }\end{array}$ \\
\hline Nebraska & Illegal & N/A & N/A & $\begin{array}{l}\text { NEB. REV. STAT. } \\
\S 28-416(2017) \text {. }\end{array}$ \\
\hline Nevada & Legal & $\begin{array}{c}\text { No. NEV. REV. STAT. } \\
\S \S 453 \mathrm{~A} .800 \text { and } \\
453 \mathrm{D} .100(2)(\mathrm{a}) .\end{array}$ & $\begin{array}{c}\text { Yes. NEV. REV. STAT. } \\
\S 613.333 .\end{array}$ & $\begin{array}{c}\text { NEV. REV. STAT. } \\
\S \S 453 A .010- \\
\text { 453A.810 } \\
\text { (2017); NEV. } \\
\text { REV. STAT. } \S \S \\
\text { 453D.010- } \\
\text { 453D.600 } \\
\text { (2017). }\end{array}$ \\
\hline $\begin{array}{c}\text { New } \\
\text { Hampshire }\end{array}$ & Medical & $\begin{array}{l}\text { No. N.H. REV. STAT. } \\
\text { ANN. § 126- } \\
\text { X:3(III)(c). }\end{array}$ & $\begin{array}{l}\text { No. N.H. REV. STAT. } \\
\text { ANN. } § 126-X: 4(V I) \text {. }\end{array}$ & $\begin{array}{c}\text { N.H. REV. STAT. } \\
\text { ANN. } \S \S 126-X- \\
: 1 \text { to } 126-X: 12 \\
\quad(2018) .\end{array}$ \\
\hline New Jersey & Medical & $\begin{array}{c}\text { No. N.J. STAT. ANN. } \\
\text { § 24:6I-6.1(c); see } \\
\text { Wild v. Carriage } \\
\text { Funeral Holdings, } \\
\text { Inc., 2020 WL } \\
\text { 1144882 (N.J. Mar. } \\
\text { 10, 2020). }\end{array}$ & $\begin{array}{c}\text { Yes. N.J. STAT. ANN. } \S \\
\text { 24:6I-6.1(a)-(b). }\end{array}$ & $\begin{array}{c}\text { N.J. STAT. ANN. } \\
\$ \S 24: 6 \mathrm{I}-1 \text { to } \\
24: 6 \mathrm{I}-16 \text { (2019); } \\
\text { Wild v. Carriage } \\
\text { Funeral } \\
\text { Holdings, Inc., } \\
\text { No. A-91 } \\
\text { September Term } \\
2018 \\
082836,2020 \\
\text { WL 1144882 } \\
\text { (N.J. Mar. 10, } \\
\text { 2020). }\end{array}$ \\
\hline
\end{tabular}




\begin{tabular}{|c|c|c|c|c|}
\hline New Mexico & Medical & $\begin{array}{l}\text { No. N.M. STAT. ANN. } \\
\text { § 26-2B-9(B). }\end{array}$ & $\begin{array}{l}\text { Yes. N.M. STAT. ANN. } \\
\$ 26-2 B-9(A) .\end{array}$ & $\begin{array}{l}\text { N.M. STAT. ANN. } \\
\S \S 26-2 \mathrm{~B}-1 \text { to } \\
\text { 26-2A-7(2019); } \\
\text { Garcia v. Tractor } \\
\text { Supply Co., } 154 \\
\text { F.Supp.3d 1225 } \\
\text { (D. N.M. 2016). }\end{array}$ \\
\hline New York & Medical & $\begin{array}{l}\text { No. N.Y. PUB. } \\
\text { HEALTH LAW } \S \\
\text { 3369(2). }\end{array}$ & $\begin{array}{c}\text { Yes. N.Y. PUB. } \\
\text { HEALTH LAW } \S 3369 .\end{array}$ & $\begin{array}{c}\text { N.Y. PUB. } \\
\text { HEALTH LAW } \S \S \\
\text { 3306-3369-E } \\
\text { (2006); N.Y. } \\
\text { COMP. CODES R. } \\
\text { \& REGS. tit. 10, } \S \\
\text { 1004.18 (2015). }\end{array}$ \\
\hline $\begin{array}{c}\text { North } \\
\text { Carolina }\end{array}$ & Illegal & N/A & N/A & $\begin{array}{l}\text { N.C. GEN. STAT. } \\
\S \S 90-86 \text { to } 90- \\
113.8(1971) .\end{array}$ \\
\hline North Dakota & Medical & $\begin{array}{l}\text { No. N.D. CENT. } \\
\text { CODE § 19-24.1- } \\
34(2) .\end{array}$ & N/A & $\begin{array}{c}\text { N.D. CENT. } \\
\text { CODE } \S \S 19- \\
24.1-01 \text { to } 19- \\
24.1-40(2019) \text {. }\end{array}$ \\
\hline Ohio & Medical & $\begin{array}{l}\text { No. OHIO REV. CODE } \\
\text { ANN. § } \\
3796.28(\mathrm{~A})(1) .\end{array}$ & $\begin{array}{l}\text { No. OHIO REV. CODE } \\
\text { ANN. § 3796.28. }\end{array}$ & $\begin{array}{c}\text { OHIO REV. CODE } \\
\text { ANN. } \S \S \\
3796.01-3796.30 \\
(2020) .\end{array}$ \\
\hline Oklahoma & Medical & $\begin{array}{c}\text { No. } 63 \text { OKL. STAT. } \S \\
425(\mathrm{~B})\end{array}$ & $\begin{array}{c}\text { No. } 63 \text { OKL. STAT. } \S \\
425(B)\end{array}$ & $\begin{array}{c}\text { OKL. STAT. tit. } \\
63, \S \S 420- \\
427.23(2019)\end{array}$ \\
\hline Oregon & Legal & $\begin{array}{c}\text { No. OR. REV. STAT. } \\
\text { 475B.794. }\end{array}$ & $\mathrm{N} / \mathrm{A}$ & $\begin{array}{c}\text { OR. REV. STAT. } \\
\S \S 475 \text { B. } 785- \\
475 \text { B.949, } \\
475 B .020 \\
\text { (2018); OR. REV. } \\
\text { STAT. } \S \S \\
\text { 475B.005- } \\
\text { 475B.548 } \\
\text { (2016); Emerald } \\
\text { Steel Fabricators, } \\
\text { Inc. v. Bureau of } \\
\text { Labor and } \\
\text { Indust., 230 P.3d } \\
\text { 518 (Or. 2010) } \\
\text { (en banc). }\end{array}$ \\
\hline Pennsylvania & Medical & $\begin{array}{c}\text { No. } 35 \text { PA. CONS. } \\
\text { STAT. \& } \\
10231.2103(b)(2) .\end{array}$ & $\begin{array}{l}\text { Yes. } 35 \text { PA. CONS. } \\
\text { STAT. \& } \\
10231.2103(\mathrm{~b})(1) .\end{array}$ & $\begin{array}{c}35 \text { PA. CONS. } \\
\text { STAT. } \S \S \\
10231.510 \\
10231.1309 \\
10231.2103 .\end{array}$ \\
\hline
\end{tabular}




\begin{tabular}{|c|c|c|c|c|}
\hline Rhode Island & Medical & $\begin{array}{l}\text { No. R.I. GEN. LAWS } \\
\S 21-28.6-7(\mathrm{~b})(2) .\end{array}$ & $\begin{array}{l}\text { Yes. R.I. GEN. LAWS } \S \\
21-28.6-4(\mathrm{e}) .\end{array}$ & $\begin{array}{c}\text { R.I. GEN. LAWS } \\
\S \S 21-28.6-4,21- \\
\text { 28.6-7 (2019); } \\
\text { Callaghan v. } \\
\text { Darlington } \\
\text { Fabrics Corp., } \\
\text { No. PC-2014- } \\
\text { 5680, } 2017 \text { WL } \\
\text { 2321181 (R.I. } \\
\text { Super. May 23, } \\
\text { 2017). }\end{array}$ \\
\hline $\begin{array}{c}\text { South } \\
\text { Carolina }\end{array}$ & Illegal & N/A & N/A & $\begin{array}{c}\text { S.C. CODE } \\
\text { ANN. } \S \S 44-53- \\
10 \text { to } 44-53- \\
1970 .\end{array}$ \\
\hline South Dakota & Illegal & N/A & N/A & $\begin{array}{c}\text { S.D. CODIFIED } \\
\text { LAWS } \S \S 22-42-1 \\
\text { to } 22-42-22 \\
(2020) .\end{array}$ \\
\hline Tennessee & Illegal & N/A & $\mathrm{N} / \mathrm{A}$ & $\begin{array}{c}\text { TENN. CODE } \\
\text { ANN. } \S \S 39-17- \\
401 \text { to } 39-17-455 \\
\text { (2017). }\end{array}$ \\
\hline Texas & Medical & N/A & N/A & $\begin{array}{c}\text { TEX. OCC. CODE } \\
\S \S 169.001- \\
69.005(2019) .\end{array}$ \\
\hline Utah & Medical & N/A & N/A & $\begin{array}{c}\text { UTAH CODE } \\
\text { ANN. } \S \S 4-41- \\
401 \text { to } 4-41-404 \\
\text { (2019). }\end{array}$ \\
\hline Vermont & Legal & $\begin{array}{l}\text { No. VT. STAT. ANN. } \\
\text { tit. } 18, \S 4230 \mathrm{a}(\mathrm{e})(1) .\end{array}$ & $\begin{array}{l}\text { No. VT. STAT. ANN. } \\
\text { tit. } 18, \S 4230 \mathrm{a}(\mathrm{e})(2) \text {. }\end{array}$ & $\begin{array}{c}\text { VT. STAT. ANN. } \\
\text { tit. } 18, \S \S 4230 \text {, } \\
4471-4474 \mathrm{~m} \\
(2018) .\end{array}$ \\
\hline
\end{tabular}




\begin{tabular}{|c|c|c|c|c|}
\hline Virginia & Medical & N/A & N/A & $\begin{array}{c}\text { VA. CODE ANN. } \\
\text { § 54.1-3408.3 } \\
\text { (2019); Va. HB } \\
\text { 1251, 2020 Reg. } \\
\text { Sess. (Va. 2020). }\end{array}$ \\
\hline Washington & Legal & $\begin{array}{l}\text { No. WASH. REV. } \\
\text { CODE } § \\
\text { 69.51A.060(4). }\end{array}$ & $\mathrm{N} / \mathrm{A}$ & $\begin{array}{c}\text { WASH. REV. } \\
\text { CODE } \S \S \\
\text { 69.51A.005- } \\
\text { 69.51A.900 } \\
\text { (2015); Roe v. } \\
\text { TeleTech } \\
\text { Customer Care } \\
\text { Mgt. (Colorado) } \\
\text { L.L.C., 257 P.3d } \\
\text { 586 (Wash. } \\
\text { 2011); WASH. } \\
\text { REV. CODE } \S \\
\text { 69.50.4013 } \\
\text { (2017); WASH. } \\
\text { ADMIN. CODE } \S \S \\
\text { 314-55-005 to } \\
\text { 314-55-540 } \\
\text { (2013). }\end{array}$ \\
\hline West Virginia & Medical & $\begin{array}{c}\text { No. W. VA. CODE } \S \\
\text { 16A-15-4(b)(2). }\end{array}$ & $\begin{array}{c}\text { Yes. W. VA. CODE } \S \\
16 \mathrm{~A}-15-4(\mathrm{~b}) .\end{array}$ & $\begin{array}{c}\text { W. VA. CODE } \S \S \\
\text { 16A-5-10, 16A- } \\
\text { 15-4 (2017). }\end{array}$ \\
\hline Wisconsin & Illegal & N/A & $\mathrm{N} / \mathrm{A}$ & $\begin{array}{c}\text { WIS. STAT. } \S \S \\
961.001-961.577 \\
(2019) .\end{array}$ \\
\hline Wyoming & Illegal & N/A & N/A & $\begin{array}{l}\text { WYO. STAT. } \\
\text { ANN. } \S \S 35-7- \\
1001 \text { to } 35-7- \\
1063(1971)\end{array}$ \\
\hline
\end{tabular}

